$\begin{array}{cl}\begin{array}{c}\text { Revue } \\ \text { de /histoire }\end{array} & \text { Revue de l'histoire des religions } \\ \text { des religions } & \begin{array}{l}\mathbf{3} \mathbf{2 0 1 0} \\ \text { Varia }\end{array}\end{array}$

\title{
Toward a History of the Portuguese Inquisition Trends in Modern Historiography (1974-2009)
}

Pour une histoire de l'Inquisition portugaise. Orientations de l'historiographie moderne (1974-2009)

\section{Giuseppe Marcocci}

\section{OpenEdition}

\section{Journals}

Electronic version

URL: http://journals.openedition.org/rhr/7622

DOI: $10.4000 /$ rhr.7622

ISSN: 2105-2573

\section{Publisher}

Armand Colin

\section{Printed version}

Date of publication: 1 October 2010

Number of pages: $355-393$

ISBN: 978-2200-92657-1

ISSN: 0035-1423

\section{Electronic reference}

Giuseppe Marcocci, « Toward a History of the Portuguese Inquisition Trends in Modern Historiography (1974-2009) », Revue de l'histoire des religions [Online], 3 | 2010, Online since 01 October 2013, connection on 04 May 2019. URL : http://journals.openedition.org/rhr/7622 ; DOI : 10.4000/rhr.7622

This text was automatically generated on 4 May 2019.

Tous droits réservés 


\title{
Toward a History of the Portuguese Inquisition Trends in Modern Historiography (1974-2009)
}

Pour une histoire de l'Inquisition portugaise. Orientations de l'historiographie moderne (1974-2009)

\author{
Giuseppe Marcocci
}

\section{The Portuguese Inquisition : classic and modern historiography}

1 One and a half centuries after the publication of the work that inaugurated the classic historiography on the subject - the História da origem e estabelecimento da Inquisição em Portugal (1854-59) by Alexandre Herculano -, a comprehensive history of the Portuguese Inquisition (1536-1821) has yet to be written. One could speculate at length about the reasons for this historiographical vacuum, which distinguishes the Portuguese Inquisition from both the Spanish as well as the Roman Inquisition, encompassing the controversy that has characterised historical interest in the Portuguese Holy Office, from its remote beginnings in the modern age up to the confessional concerns that are still evident well after the end of Salazar's dictatorship (1932-74). This is even more inexplicable when one considers the reduced number of tribunals of the Portuguese Inquisition (four in all, including that of Goa in India) as compared to its counterparts in Spain and Italy between the late $15^{\text {th }}$ century and the first half of the $19^{\text {th }}$ century, as well as the fact that a considerable patrimony of sources produced by the Portuguese Holy Office are concentrated in a single State archive - the Torre do Tombo in Lisbon.

It is not enough to cite external factors. While it is true that Juan Antonio Llorente published his Histoire critique de l'Inquisition d'Espagne in Paris during the early $19^{\text {th }}$ century, at the beginning of the following century the American historian Henry Charles Lea was able to overcome limitations and peruse an already rich scientific literature 
about the Spanish Inquisition to produce an unsurpassed four-volume synthesis of this historiography. ${ }^{1}$ After the work by Henry Kamen, with the return of intellectual freedom after the end of Franco's regime (1939-75), growing numbers of foreign historians have worked alongside Spanish colleagues and put forth proposals to reinterpret and reformulate the corpus of existing works, reflecting an apparently inexhaustible need to ponder upon the significance of the actions of the Holy Office in the context of Spain and Catholic Europe. ${ }^{2}$ Notwithstanding the drop in the number of studies from the 1990s onwards, general histories of the Spanish Inquisition have perhaps become more streamlined and their number continues to grow. ${ }^{3}$

3 Similarly, an overview of the history of the Inquisition in Italy can be found in the latest book by Andrea Del Col, who even encompasses the Middle Ages and more contemporary times. ${ }^{4}$ Thus, the desire expressed by John Tedeschi in his preface to the Italian edition of his collection of essays entitled The Prosecution of Heresy has gradually begun to be transformed into reality. The translation of Tedeschi's work was published a year after the great fresco by Adriano Prosperi about the role of the Holy office in the history of the Church in Italy and in the gradual construction of a unified State..$^{5}$ Other examples, published both before and after the work by Del Col, reveal how, after a long period characterised by a vast mass of research on specific subjects, the historiography in this area has matured as it became increasingly evident that there was a pressing need for a global overview that could help overcome the difficulties arising from the loss and dispersion of sources, due to the political fragmentation of the Italian peninsula during the Ancien Régime. ${ }^{6}$ In fact, it is in Italy itself, a country that has hosted several conferences during the past twenty years embracing the idea of comparing the different Inquisitions, that has been realised a four-volume dictionary spanning the universal history of the Holy Office. ${ }^{7}$

4 Less than ten years have passed since Jean-Pierre Dedieu and René Millar Carvacho lamented, justifiably, the lack of a dialogue amongst the historiographies pertaining to the three Inquisitions of the modern age. ${ }^{8}$ However, an attentive perusal of the best insights afforded by studies about the Spanish Inquisition contributed toward a renewal of interest in the institutional history of the Holy office in Italy, already visible in an article by Prosperi published in $1988 .{ }^{9}$ In contrast, during the same years, scholars of the Portuguese Inquisition paid less attention to the bibliography on the Spanish tribunal, even if the Portuguese model had characteristics more similar to the Spanish one than the Roman Holy Office had. ${ }^{10}$ This insularity undoubtedly reflected the continued propensity to favour a national approach to the study of the Inquisition, but was also the result of a traditional absence of interest in a comprehensive awareness of the institutional history of the Tribunal of the Faith in Portugal and an inclination to represent the more dramatic episodes in a controversial manner. ${ }^{11}$

While contemplating the origin of a tendency that unites modern historiography (an expression I use here to identify the new generation that has written about the Portuguese Inquisition after democracy returned to Portugal in the wake of the 1974 revolution) with the main exponents of classic historiography, one must consider the enduring influence of a landmark decision by Herculano. While justifying his entirely political choice - as pointed out by Jorge Borges de Macedo - of focusing on the years when the Holy Office was founded, which enabled a more effective denunciation of the risks of an absolute monarchy, this liberal novelist dismissed concrete activities about the remaining centuries of the Inquisition's history as a 'more monotonous than instructive' 
object of study. ${ }^{12}$ Fifty years later, António Baião once again set out from the $16^{\text {th }}$ century in a series of articles, the first of which was published in 1906, the same year in which the first volume of the work by Lea was released. Baião's articles continued to be published in subsequent years, while the decreta issued during the second half of the $16^{\text {th }}$ century by the Roman Congregation of the Holy Office were also released in a printed edition. ${ }^{13} \mathrm{He}$ thus set in motion the study of the organisation and norms of the Portuguese Inquisition, leaving for posterity a work that has yet to be surpassed. ${ }^{14}$

6 As for the rest, the best classic historiography was produced during the period of the Republican crisis and under the dictatorship of António de Oliveira Salazar. While João Lúcio de Azevedo advanced a vast analysis of the almost three hundred years of history of the Portuguese Inquisition in a book that, despite its nationalist overtones, continues to be the point of departure for any history of the relations between the Inquisition and New Christians - the descendants of the Jews who were converted en masse in 1497 and who were the main target of the Holy Office for about two centuries - no one really followed his example..$^{15}$ Fascinated by the alluring question of the impact that the Inquisition had on religious and cultural life in Portugal, two Portuguese historians, Mário Brandão and José Sebastião da Silva Dias, also devoted their own research to the $16^{\text {th }}$ century, in the wake of studies about Portuguese humanists by the French hispanist Marcel Bataillon. ${ }^{16}$ The contribution by Israël-Savator Révah is situated midway between the latter works and more specialised texts on the clash between the Inquisition and New Christians. Primarily aimed at the $16^{\text {th }}$ century, although not limited to this period, the studies by this French historian are renowned, above all, for the way in which he defended the thesis of a widespread, albeit heterogeneous, adherence by the descendants of converted Jews to a marrano or crypto-Jewish religiosity, which contained the seeds of a 'potential Judaism'. ${ }^{17}$ Révah partially revived Cecil Roth's proposals, followed by Yosef Hayim Yerushalmi during the early 1970s. ${ }^{18}$ Meanwhile, the fiery dispute that pitted Révah against the Portuguese scholar António José Saraiva, who mantained a view of inquisitorial persecution dictated by economic and social interests and a substantial conversion of New Christians to the Catholic faith, had a notable impact. ${ }^{19}$ At the same time, in Brazil, likewise under a dictatorship, José Gonçalves Salvador and Anita Novinsky published monographs, which served as the basis for a school in its own right. ${ }^{20}$

7 The Révah-Saraiva debate heralded, to a certain extent, the epilogue of the best classical historiography, which, in years of an absolute cultural hegemony of the Church in Portugal, had concentrated on the consequences of intellectual control or the reasons for the anti-Jewish repression pursued by the Inquisition. This debate also gave rise to a schism, that still characterises modern historiography, between studies about the tribunal itself - which will be examined in subsequent pages - and those about its victims, from then onwards focusing on the controversial subject of the real nature of cryptoJudaism: consequently, the Holy Office was relegated to a secondary plane and was sometimes described as a cruel and fanatical tribunal and at other times as a cold and calculating institution; but nevertheless an institution that was always identical in space and time. ${ }^{21}$ This was the legacy that served as a yardstick for the heterogeneous generation of historians who began to write about the Inquisition in Portugal after the 25 April 1974 revolution. 


\section{After 25 April 1974 : A new look at the Inquisition}

8 'The present makes sense of the past and it is the past that gives us a reference or a perspective by which to understand the present' : thus reads the preface of the first work on the Inquisition after Portugal returned to democracy in 1974 in the wake of the socalled 'Carnation Revolution'. It was in fact precisely in the months just after 25 April 1974, when Silva Dias traded in his academic robes to become a militant politician, that this professor at the University of Coimbra completed and published a text that he had been working on for some time. It examined the case of the Augustinian friar Valentim da Luz, the first Portuguese to have been condemned to death for Lutheranism by the Inquisition (1562). The long introduction by Silva Dias, which opened with a dedication to 'all those who have fought for and still continue to fight for democracy and socialism in Portugal', appeared to mark a turning point in studies about the Portuguese Inquisition. Once again, the $16^{\text {th }}$ century was viewed as the decisive moment in the history of the Holy Office. However, after the Révah-Saraiva debate, this choice of having resumed such studies setting out from an old Christian who was eventually burned at the stake sent out a message about the more general implications of the profound impact that the Inquisition had on Portugal's history. The political overtones visible in the vocabulary used in the introduction by Silva Dias (starting with the 'ideological conflicts of the $16^{\text {th }}$ century' mentioned in the title) do not detract from the rigorous analysis of what is still today the best study about the penetration of religious dissent and internal struggles within an order - the Augustinians - in Portugal during the modern age, finally revealing the impact that the Holy Office had on the internal balance of the Portuguese Church. ${ }^{22}$

Nonetheless, the path that had been paved by Silva Dias did not inspire scholars to pursue this line of research in subsequent years. In Spain, new and significant research, distinguished by multiple approaches and fields of study, resulted in a rapid overhaul of the image of what was the larger of the two Iberian Inquisitions, about which Jaime Contreras and Gustav Henningsen then realised a systematic statistical analysis. ${ }^{23}$ On the contrary, the historiography about the Portuguese Inquisition proved to be less bold and produced fewer results. Also in vain was the noteworthy effort by Charles Amiel to provide a concise overview of archival sources and the institutional characteristics of the Portuguese Holy Office that he presented at the international conference held in Copenhagen-Skjoldenæasholm in 1978, where a select group of Inquisition specialists attempted to establish a common research programme..$^{24}$ The anticipation that preceded this conference is patently evident in a short report describing the work being done, indicating that the objective of the symposium was to dispel the secrecy that for centuries had shrouded the letters and activities of the inquisitorial tribunals : it 'must have made Torquemada turn in his grave. Neither the grand inquisitor of Spain nor his no less notorious colleagues could ever have dreamed that this confidential body of material' 'would fall into secular hands'. ${ }^{25}$ The project revolved around a global survey of the sources preserved in the archives and the need to quantify them, as though possessing reliable numbers was the only valid ground for a scientific study of the history of the Holy office. Only a solid base of general and specific knowledge could have avoided the reappearance of passionate and partial syntheses. On the other hand, it was still necessary to justify the choice of focusing on the internal working of the Inquisition, its strategies and its social roots, owing to concerns of appearing to defend a tribunal that 
for centuries had been synonymous with intolerance, obscurantism and violence. These were the years in which Tedeschi revealed how important it had been for his career as a researcher to discover that inquisitorial procedures were shrouded by a negative myth that did not truly correspond to the reality of a tribunal that was, at times, more moderate than the secular courts : one only needed to consult a manual for inquisitors, for example, to verify that expressions such as carcere perpetuo (life imprisonment) in the case of the Roman Inquisition actually implied a far more limited sentence (3 years). ${ }^{26}$ Even if an international network was created, tools were identified and other meetings were held, the goals established in Copenhagen were never realised..$^{27}$ But, directly or indirectly, they had an undeniable influence on Inquisition scholars during the next two decades.

Meanwhile, two distinct tendencies had emerged that would characterize the nascent modern historiography of the Portuguese Inquisition. On the Catholic side, an attempt was made to contain the risks of a wave of studies with anti-clerical overtones by means of erudite works and the publication of documents, accompanied by an eloquent insistence on attenuating historical circumstances to the detriment of an in-depth interpretation of available sources and well-known facts. This was balanced by the production of a new generation of scholars of different political orientation, all of whom had little interest in the old issue of whether to absolve or condemn the Holy Office, instead revealing a fascination for statistics and quantitative history.

11 The greatest exponent of the former tendency was the canonical Isaías da Rosa Pereira. A perusal of his prolific historiographic production, which began during the second half of the 1970s and spanned over two decades, reveals a hint of apologetic overtones not just in his introduction to the sources but also in his very selection of them. This was aimed, on the one hand, at preserving the image that Portuguese Catholicism (blemished by the Valentim da Luz case) was as pure as the driven snow, while on the other hand it sought to dispel the spectre of the black legend. While he made available an extremely useful corpus of documents about the Inquisition's procedures and its daily functioning, this is marred by the fact that he tended to present them as self-evident sources, which did not require any particular interpretative effort or other insights. ${ }^{28}$ The effort to normalise the Holy office is associated with a significant selection of published cases (a meritorious work in itself), reinforcing the impression that the ideas of the Reformation had made no headway amongst the Portuguese Old Christians. ${ }^{29}$ Protestants would always have been foreigners in Portuguese territories, although even a cursory reading of the documents published by Rosa Pereira shows the network of support and cooperation that the Portuguese offered individuals who later ended up in the clutches of the Inquisition. So much so that the real question should be : why was an almost systematic decision made to not prosecute Portuguese who were suspected to be or were denounced as 'Lutherans' ? The question remains unanswered even today. ${ }^{30}$

12 An equally enduring influence proved to be the scholars who, setting out from the legitimate need to ascertain the overall dimensions of the repressive impact and the institutional presence of the Holy office in Portuguese society, often ended up by substituting more profound and detailed analyses about the 'social war' triggered by the Inquisition with the apparent eloquence of numbers (a temptation reinforced by the fact that about 40,000 inquisitorial judicial files are considered to be preserved at the Torre do Tombo). Even if the inventory published by Luís de Bivar Guerra had already revealed discrepancies between the trials recorded in the registers and those that are effectively 
filed in the Portuguese central archive, in the 1970s José Veiga Torres began to compile statistics based on calculations pertaining to the collections of the Torre do Tombo. ${ }^{31}$ After some errors in his first article, he chose to concentrate on the tribunal in Coimbra, which had already been the subject of a short essay by José do Nascimento Raposo. ${ }^{32}$ In the mid-1990s, Veiga Torres proposed a study based on numbers, whereby, after examining the composition of the inquisitorial officials known as the familiars, instead of the victims of the trials, he concluded, unlike Saraiva, that the mercantile bourgeoisie had found in the Holy office (or rather in an affiliation with its officialdom that exonerated them from suspicions of Jewish origins) an instrument that promoted and legitimised their own social ascent. ${ }^{33}$

13 New horizons were charted by some research that appeared in the early 1980s, especially with regard to the geography of the Inquisition. The essay about the Algarve by Joaquim Romero Magalhães broke with the image of the Holy Office as a monolithic institution, revealing how it had penetrated diverse areas of Portuguese territory owing to contingent factors and affirming that it was necessary to reconnect the history of the tribunal to a more concrete evolution in time and space. ${ }^{34}$ Francisco Bethencourt appealed for greater attention to be paid to the districts of the Inquisition. ${ }^{35}$ There was also renewed interest in inquisitorial censorship and research in this area was extended to encompass periods well beyond the $16^{\text {th }}$ century, examining the $17^{\text {th }}$ and $18^{\text {th }}$ centuries, neglected until then. ${ }^{36}$

14 The difficulties faced by a historiography that was unable to construct an authentic dialogue between scholars seemed to have almost been overcome by the mid-1980s. The turning point occurred in 1987. Some works were published at the time that promised to bridge the gap between studies regarding the Portuguese and the Spanish Inquisitions. Despite the disparities in the level of papers, a major conference was held that year in Lisbon and in São Paulo, which brought together dozens of historians from various countries, reflecting the vast scope of the research that had been developed or had yet to be developed with regard to the Portuguese Inquisition. Anyone who flips through the pages of the proceedings published after the conference can even today feel the sensation of a universe that was opening up, a world that was being discovered for the first time. This was highlighted by Maria Helena Carvalho dos Santos, who underscored the participation of 'all interested scholars, who could reveal or discuss their own work and lines of research', 'even if they used diverse methodologies', so as to promote a vision of history as 'an issue that concerns everybody and not just specialists' ${ }^{37}$ It truly reflected the new democratic winds that were blowing over Portugal and Brazil, the two countries that hosted the conference. Even if many of the suggestions that were propounded were never pursued, others sowed the seeds for fruits that would be harvested during the next two decades.

There was no dearth of negative reactions. Maria José Ferro Tavares did not hesitate to distance herself from the new openness of the recently concluded conference, in which she herself had also participated. The severity of her public judgement contributed toward stifling a new spirit of cooperation at birth; this was even more critical because these views had been expressed by someone who, based on meticulous archival research about the Inquisition, was rewriting much of the history of the conversos in $16^{\text {th }}$ century Portugal, especially studying the tension between 'desired integration and the integration which was imposed by the Crown' and 'the hermetic nature of New Christians'. ${ }^{38}$ 

line of analysis about popular beliefs in Portugal during the modern age and the methods of control employed by the Portuguese inquisitors. He also encouraged and stimulated renewed interest in the institutional history of the Inquisition, by means of a brief article. ${ }^{39}$ In the same year, António Borges Coelho published the first study about a long period of the history of a single district. His work on the Inquisition in Évora from its foundation to the mid- $17^{\text {th }}$ century was partly influenced by international historiography, attempting to put together quantitative data, examples and the everyday functioning of the Inquisition against an overall backdrop, which is, however, not always reliable. ${ }^{40}$

Roman and Portuguese Inquisitions to be 'modern', reflecting upon their different 'models' in a quest for a comparative history of the three tribunals. ${ }^{41}$ Portuguese scholars still responded cautiously to this apparent sign of openness. In any case, new descriptions of the collections of the Torre do Tombo seemed to herald another stage of research. ${ }^{42}$

The number of works available about the Portuguese Inquisition increased perceptibly from the 1990s onwards, in contrast to the tendency witnessed with regard to the studies on the Spanish tribunal, but in keeping with the historiography pertaining to the Holy Office in Italy, which had, over the course of time, become a point of reference even for renowned Portuguese scholars, ranging from Bethencourt to José Pedro Paiva. With rare exceptions, the victims of the Inquisitions emerged as a separate field of research, in close interaction with international historiography : this is especially visible, above all, in the case of the New Christians who continued to live in Portugal, also due to the networks created by the Sephardite Diaspora, and, to a lesser extent, in the case of witchcraft and popular beliefs. On the other hand, it is possible to find a considerable number of books and articles about the Inquisition as a power and as an institution, both at the level of its internal organisation as well as the aspect of social and territorial control. If these perspectives question the relationship between the Inquisition and the Crown and secular authorities, the attention of historians has focused above all on the not always linear relations between the justices of the faith and other agents of the Portuguese Church, headed by bishops and regular clerics, with the inevitable fallout while defining their respective jurisdictions. A third field of analysis pertains to the activities and the diffusion of the Holy Office in imperial territories. Although this area still suffers from an overly excessive tendency to engage in studies on a regional scale, there has been a partial renewal of interest in research about the tribunal of Goa, after the pioneering monograph by Baião on the affairs of the only stable headquarters ever to be established by the Inquisition outside Portugal. ${ }^{43}$

\section{The Inquisition, the modern State and society}

19 Despite its avowed aim of providing the first overall history of the modern Inquisitions, the volume that Bethencourt dedicated in 1994 to a comparative analysis of the Holy Office in Portugal, Spain and Italy gave rise to mixed reactions. ${ }^{44}$ Amongst scholars of the Portuguese Inquisition it was, above all, the research proposals pertaining to the institutional sphere of the Inquisition and its means of social affirmation that achieved a consensus. Written on the basis of an ample bibliographic survey, Bethencourt's book remains a milestone even today. In the case of the Portuguese Inquisition, apart from new factual knowledge, it gave up contrasting ideological positions regarding the hereditary 
nature of the tribunal. It also encouraged studies about the Inquisition, overcoming the habitual national barriers and expanding the tools available to historians engaged in other social sciences, ranging from anthropology to sociology. Based on a long-term analysis of rites and procedures (auto da fé, processions), the internal organisation (the genesis of the institutions, relationship between local structures and higher authorities, periodical reports, correspondence), models of action (pace of repression, strategies, visits) and the symbolic dimension (representations, emblems, internal memory), Bethencourt's approach has one flaw, in my view, which is that of neglecting the wealth of individual trials as a privileged source to understand the concrete historical evolution of the inquisitorial tribunals, limiting itself to contemplating them from the outside while merely extracting comprehensive statistical data. ${ }^{45}$

Bethencourt's monograph was followed by a series of reconstructions of inquisitorial bureaucracy and its impact on areas corresponding to the district of a single tribunal or more limited regions. This was complemented by the study by Elvira Cunha de Azevedo Mea about the Coimbra Inquisition in the $16^{\text {th }}$ century $;^{46}$ the volume by Paulo Drumond Braga about its presence in the Azores ${ }^{47}$ the book by Michèle Janin-Thivos Tailland about the district of Évora from the second half of the $17^{\text {th }}$ century to the abolition of the inquisitorial tribunal in Portugal ${ }^{48}$ (as well as Ph.D. dissertations, focusing on the repression of New Christians, by Maria do Carmo Teixeira Pinto about Elvas in the mid-17 th century and by Claude Stuczynski about Bragança during the $16^{\text {th }}$ century). ${ }^{49}$ Geography, the type of personnel, the pace of repression and the punishments meted out continued to be the most developed aspects in these works, as well as in those works that have focused on the itinerant nature of territorial and social monitoring on the part of the Holy Office by means of the long arm of the inquisitorial visits. ${ }^{50}$ The progress that was achieved further highlighted the dearth of analyses regarding the Lisbon tribunal, which was undoubtedly the most important of all the tribunals that were active in Portugal and in the empire. ${ }^{51}$

21 The study of the social networks that sustained the Spanish Inquisition is a classic theme in the historiography ${ }^{52}$ In recent times the first surveys have been carried out regarding this complex subject also in the case of the Portuguese Inquisition. An ambitious plan has been set in motion to prepare a comprehensive prosopography of familiars based on qualification processes, presently limited to a single volume. ${ }^{53}$ Since the capillary diffusion of peripheral bodies served to ensure a greater effectiveness on the part of the Inquisition during the early $17^{\text {th }}$ century, it is no coincidence that existing monographs tend to focus on Brazil, a vast colonial territory that did not have a fixed tribunal. ${ }^{54}$ There is a lack of suitable studies regarding other minor functionaries active at a local level, starting from the commissaries, in charge of pointing out suspected cases and compiling testimonies, while preliminary research about the brotherhoods that united inquisitorial officials both in Portugal as well as in imperial territories has matured in the wake of Bethencourt's seminal work..$^{55}$

Moving from the inquisitorial apparatus to the upper hierarchies, the scenario is surprisingly disheartening. There are few available works, which are often outdated and until now have not shed any light on the role of the delicate power balances in the functioning of the higher bodies of the tribunal or that of clientary ties in the selection of internal personnel. There is still no overview of the activities of an inquisitor-general, while the working of the General Council of the Holy office also remains unexplored..$^{56}$ Although they have often been claimed, prosopographic studies have never been fully 
developed, despite the fact that the Torre do Tombo has a wealth of documents that could easily enable scholars to recreate almost every stage of an inquisitorial career. ${ }^{57}$

Amidst the omissions of the historiography pertaining to the Portuguese Inquisition one finds the absence of general analyses at a normative level, based on regulations ( regimentos), codes that were periodically revised and which regulated the organisation and the procedures of inquisitorial tribunals..$^{58}$ Only the 'edicts of faith' have been deemed to be a possible source for studying crypto-Judaism. ${ }^{59}$ On the contrary, decrees and instructions, as well as the consultations that preceded intervention by the central authorities, or the manuals for inquisitors that proliferated during the early decades of the $17^{\text {th }}$ century, have not yet attracted the attention of scholars, whose research has been limited to the exceptional aspects of the Portuguese judicial system, especially the use of individual testimonies. ${ }^{60}$

Greater precision in terms of defining the juridical nature of the Portuguese tribunal is also an essential condition to be able to respond to a question that is critical for any study of the Iberian Inquisitions : the relationship with the monarchy. ${ }^{61}$ The absence of this critical issue could perhaps help explain the main reason for a surprising dearth of comparisons, on the part of historians studying the Portuguese Inquisition, with the proposals of António Manuel Hespanha, who firmly upheld the intrinsic weakness of the modern State. ${ }^{62}$ The silence regarding Portugal is in stark contrast to the abundant studies about the relationship between the Crown and the Inquisition in Spain as well as the attention that is paid in Italy to the model of a history of Catholic justice as proposed by Paolo Prodi. ${ }^{63}$ The $17^{\text {th }}$ century, which particularly attracted Hespanha's attention, would be an ideal common ground, since the best results provided by those who view the Inquisition as a power, reconstructing the informal, institutional and economic relations with the Crown, have been achieved thanks to research on the relations between the tribunal and the royal authority during the period when the Habsburgs ruled Portugal (1580-1640). ${ }^{64}$ The impression is that, if sovereigns maintained a considerable level of control over the Inquisition, the time has come to discuss whether the Holy Office peacefully submitted to the Crown : the recurring tensions between inquisitors-general and the kings (Cardinal Infant Dom Henrique with King Dom João III in 1548 and with King Sebastião in $1576 ;{ }^{65}$ the open clash between Dom Francisco de Castro and João IV in the mid- $17^{\text {th }}$ century $;^{66}$ the destitution of Dom José de Bragança by the Marquis of Pombal in 1760) ${ }^{67}$ reveal how, in critical moments of its history, the Inquisition was at the centre of a clash, with varying outcomes, between the hierarchies of the tribunal and the Crown. Naturally, this did not prevent the latter from always providing the Holy Office with material support, which is patently evident in the handful of available studies about the financial structure of the Inquisition : in this context too studies pertaining to Portugal lag behind the information that is available about Spain and Italy, although there are signs that this tendency is possibly being reversed. ${ }^{68}$

The view of the Inquisition as a composite institution of power and the recognition of the complex dynamics that regulated its actions finally promoted a new approach to its spheres of competence, the crimes committed and the social levels involved. A resumption of research and syntheses about control over intellectual life, from printing to the University, would allow a better understanding about the Inquisition's role in containing and orienting debates, which could have had not just religious but also political implications. ${ }^{69}$ On the other hand, an increasingly attentive reconstruction of the ways in which the Holy Office established a presence in the territory is being 
accompanied by an increasingly less generic awareness of the concrete social impact of the Inquisition, based on its main targets : the New Christians. The suggestion by Robert Rowland to again propose in the case of Portugal the classic model of Sotos contra Riquelmes mooted by Jaime Contreras has largely gone unheeded. ${ }^{70}$ But the traditional studies about the incessant persecution of New Christians have benefited from the research by Elvira Mea about the strategies of resistance that the accused used before the judges of the Holy office, frequently agreed upon in prisons at considerable risk. ${ }^{71}$ Indeed, the prisoners were under a special system of control (approved by the central authority and unknown to the Roman and Spanish Inquisition) based on peepholes that allowed the guards to keep a lookout for what happened in the cells at any time. As pointed out by Amiel, it enabled to charge an accused with a crime that he committed after the imprisonment. This denial of one of the most fundamental principle of the Western legal tradition was a distinctive characteristic of the Iberian Inquisitions. ${ }^{72}$ Moreover, scholars have made the first steps about the prickly question of the imposition of statutes regarding the purity of blood between the $16^{\text {th }}$ and $17^{\text {th }}$ centuries. ${ }^{73}$ Interest has also been consolidated in this latter century, during which anti-Jewish repression peaked in intensity. ${ }^{74}$ This has undoubtedly resulted in a more complex framework that can no longer be limited to a rigid representation that insists on a frontal clash between the tribunal on one side and a compact block of its victims on the other.

Some monographs are now available about the oppression of another minority present in Portugal, the so-called mouriscos, an expression used to refer to the Muslims who came to Portugal having just converted or in order to convert, in the decades after the 1497 edict expelling Muslims from the kingdom. ${ }^{75}$ In terms of studies on witchcraft the book by José Pedro Paiva about the activities of the Coimbra Inquisition and the reasons that could explain the absence of a 'witch hunt' has yet to be surpassed. ${ }^{76}$ Some signs have also begun to emerge in the direction of using the documents of inquisitorial trials to approach the composite universe of popular beliefs, with the enduring precedent set by Carlo Ginzburg's Menocchio. ${ }^{77}$ With regard to vigilance over forms of spirituality deemed to be deviant, from directing the conscience of the beatas (religious lay women) to quietism, the treatise by Pedro Vilas Boas Tavares about the Portuguese reaction to Miguel de Molinos has renewed interest in a tradition that seemed to have been interrupted after Silva Dias' book about the currents of religious sentiment. ${ }^{78}$ The Inquisition's penetration of society to the extent of being able to maintain a surveillance of individuals' most intimate habits, often far more so than the civil judicial system, can be glimpsed in studies about the tribunal's intervention in the spheres of conjugal and sexual lives, from bigamy to sodomy, up to soliciting in confessional, a special crime to keep priests under control, but whose management was often aimed at protecting their honour and that of the violated sacrament. ${ }^{79}$

\section{The Inquisition and the Church : collaboration and resistance}

The Inquisition's attention with regard to the sacrament of penitence is one of the central aspects of recent efforts to reintegrate the actions of the Holy office into the context of the broader hegemony of the Catholic Church in Portugal under the Ancien Régime. From this point of view, reflections on the role of the Inquisition in the non-linear events of Portuguese ecclesiastical justice highlight the almost total absence of studies about 
relations between inquisitors and civil magistrates. There has been renewed interest in an old question, one that was already touched upon by Fortunato de Almeida, on the part of scholars of the Portuguese Inquisition, due to the stark contrast between Bethencourt's harmonising vision, based on the efficiency of the alliance between inquisitors and other ecclesiastical agents, and an approach that is more sensitive to nuances and grey areas that emerged in the historiography about the Roman Inquisition from the 1970s onwards up to the Tribunali della coscienza by Prosperi, who insisted on a plurality of courts and subjects involved in administering the crime of heresy, according to strategies that did not always complement each other..$^{80}$

In reality, as has been seen, amongst Portuguese scholars the question of which position was applicable to the delegated apostolic tribunal, founded in 1536, as compared to the preceding ecclesiastical structure (there has recently been renewed interest in this subject as part of research on the Medieval Inquisition), ${ }^{81}$ focused above all on the authority of the bishops and has already been debated for some time. In the 1980s, the meticulous research about pastoral visits in the Coimbra region during the $17^{\text {th }}$ and $18^{\text {th }}$ centuries developed by Paiva and Joaquim de Ramos Carvalho revealed the singularity of the Portuguese episcopacy in the context of Catholic Europe during the modern age : an economically strong episcopacy that enjoyed a great deal of social prestige, dedicated to the post-Tridentine mission of re-educating society through periodical inspections policing customs, conducted by means of the instrument of visits. ${ }^{82}$ However, there is almost no trace of New Christians in episcopal sources. In the light of an orientation for prelates that was moreover marked by a tendency towards severity, how can one reconcile this with the image transmitted by inquisitorial documents, which instead seem to indicate a kingdom grappling with an endemic crypto-Judaism? Why did the bishops and their visitors not see what the inquisitors recorded almost everywhere? The first to answer this question was Paiva, in a quick but incisive article in which he proposed the idea of a division of labour between bishops and inquisitors: the former would have occupied themselves exclusively with old Christians, while the latter would have concentrated on Jewish converts ; moreover, hundreds of inquisitorial trials reveal that, as a norm, when a diocesan authority received news of a crime of crypto-Judaism, the case would be referred to the Holy office after carrying out the necessary verifications. Paiva was thus able to formulate a thesis of a close collaboration between bishops and inquisitors, subsequently adopted by all scholars. ${ }^{83}$

Elvira Mea drew attention to the singular framework afforded by the activities of the Inquisition in the region of Braga during the tenure of the Dominican friar Bartolomeu dos Mártires, who was the local archbishop between 1559 and $1581 .^{84}$ She proposed viewing the inquisitorial process as a tool to separate the wheat from the chaff in terms of denunciations against New Christians collected during pastoral visits. Having edited a comprehensive collection of sentences issued by the Coimbra Inquisition against residents in the archdiocese of Braga and in the suffragant dioceses during the administration of Bartolomeu dos Mártires ${ }^{85}$ Mea openly raised a question which, however, she did not answer: why was it that under a prelate like the Dominican archbishop, who had greatly encouraged pastoral visits, the Inquisition had persecuted a singularly scanty number of Jewish converts? I have set out on the basis of this question, examining the Portuguese sources along the guidelines proposed by Prosperi, while also incorporating the early results of the research by Stefania Pastore about the Spanish Inquisition and by an Italian 
historiography that had purposefully raised the issue of the relationship between cases in courts (external forum) and the powers of absolution of confessors (internal forum). ${ }^{86}$ With a research about the relations not just between bishops and inquisitors but also between inquisitors and confessors, likewise including missionaries (especially the Jesuits) in this overall design (Federico Palomo's research has also shed light on this issue, although he did not deal with the question of their relations with the Holy Office), I have tried to provide a less pacific and linear image of how the apostolic tribunal was implanted into Portugal during the modern age. ${ }^{87}$ The underlying idea is that the Inquisition would have undergone a process of putting down roots in Portugal, which also resulted in friction with some bishops, who opted to implement partly autonomous strategies to manage heresy; if most prelates immediately participated in building an integrated system to control orthodoxy, there was still room in the early decades of the Inquisition's activities, albeit without significant ruptures, for alternative paths, which found willing ears even amongst members of religious orders, thus transforming a sacrament with judicial implications such as the confession into a fertile ground for clashes. ${ }^{88}$ The Holy Office managed to achieve a comprehensive supremacy over the Portuguese Church only at the end of the $16^{\text {th }}$ century, thus implementing the model glimpsed by Bethencourt and Paiva.

The latter has nonetheless strongly emphasised the absence of significant differences between inquisitors and bishops in the history of the Portuguese tribunal, classifying the cases presented by me as exceptional instances. ${ }^{89}$ According to Paiva, the episcopacy would have played a central role in creating the Inquisition, without considering the ties of obedience common to prelates and apostolic magistrates with regard to a Crown that had strenuously fought to get the Holy Office and had wielded an almost absolute control over the Church in Portugal from as early as the late $15^{\text {th }}$ century ${ }^{90}$ Yet the tensions are evident even when one looks at the subdued discussion regarding the validity of forced baptisms of Jews, which occurred throughout the $16^{\text {th }}$ century, as well as, more broadly, the tendencies and limits of apologetic literature in Portugal in the early modern age. ${ }^{91}$ The debate between Paiva and me still continues and reflects, in part, two different views, one that pays more attention to the quest for a general model, while the other is more sensitive to the phenomena that emerged during its evolution. ${ }^{92}$ In both cases, it has opened up unexplored lines of research, producing results even in the no less complex area of the history of relations between the Inquisitions and religious orders during the $16^{\text {th }}$ century. ${ }^{93}$

The $17^{\text {th }}$ century continues to suffer from a dearth of first hand research about the relations between the Inquisition and other ecclesiastical powers. Following the strands of the diffusion of Jansenist ideas at the heart of the Church in Portugal and its empire, Evergton Sales Souza has provided a fascinating history of the inextricable relation between Catholic doctrines, spirituality and politics between the $17^{\text {th }}$ and $18^{\text {th }}$ centuries, which once again revived questions about the relationship between bishops and inquisitors, on the one hand, and between the Holy office and confessions, on the other. ${ }^{94}$ In particular, with regard to the former, the acrimonious conflict that developed between the archbishop of Goa, Inácio de Santa Teresa, and the Inquisition, that accused him of having proffered a Jansenist sermon (1725), resulted in a dry denial of the authority of the tribunal : after a long conflict, the Holy office was obliged to submit to the papal brief by which the Portuguese prelate was rehabilitated by the Roman Congregation of the Inquisition (1737). The tension between the reforming faction of the bishops and the 
Inquisition exploded once more into a violent dispute about the jurisdictions of confessors who violated the tenet of secrecy. This celebrated question of secrecy, or sigilismo, was the subject of an early study by António Pereira da Silva. It was taken up once more by Prosperi, who worked on Roman sources, while in his book Sales Souza has revealed his rare sensibility as a scholar of religious history. ${ }^{95}$

A promising sector for research has been opened up in recent years, that of direct relations between the Portuguese Inquisition and its Spanish counterpart, as well as with the Roman Congregation of the Holy Office. This offers possible perspectives not just for the history of concrete relations between the three modern tribunals, but also for a comparison of their institutional forms and judicial strategies. For the moment, it presents an as yet blurred image of a general collaboration between the tribunals, albeit one that did not lack friction, sometimes due to a show of force or even due to profound procedural differences. ${ }^{96}$

\section{Inquisition and Empire : a court for the world}

Many historians who have examined the Inquisition in the Portuguese overseas colonies have attentively followed the development of studies about the Holy Office in Portugal itself, as well as in the territories of the Spanish Crown or in Italy. Thus, to present their results in a different section could seem to be a forced and artificial separation. However, two aspects favour such a solution : on the one hand, the diverse historical nature of the diffusion of the Inquisition in the Iberian colonial empires as compared to the homeland, both in terms of the chronology, as well as in terms of the environmental conditions in which inquisitorial magistrates operated in the tropics; on the other hand, the existence of a tradition of scholars who, with rare exceptions like Baião, rarely deal with both levels, that of Portugal and that of the empire. In fact, the notable increase in research about the Holy Office in Portuguese colonial territories in the last two decades has resulted in a historiographic production that, in large measure, does not conform to the periods and directions of the studies that have been mentioned in the preceding pages. There is no doubt that decolonisation and the end of the dictatorship in Portugal and in Brazil ensured that, as an object of study, the Inquisition in the Portuguese empire was increasingly free of the nationalist and apologetic rhetoric that still surrounded Portuguese colonialism during the third quarter of the last century. ${ }^{97}$

Signs of this openness could already be found in various papers presented during the aforesaid Luso-Brazilian conference held in 1987, enthusiastically promoted by the doyenne of studies about New Christians in Brazil, Anita Novinsky. The same year also witnessed the publication of a volume by Laura de Mello e Souza about controlling witchcraft in Portuguese America, which, for the first time, examined the subject of the colonial Inquisition without merely limiting its gaze to the extension of the struggle between the Holy Office and conversos to the New World. ${ }^{98}$ As for the rest, although the Tribunal of the Faith never opened a permanent headquarters in Brazil - a question recently re-examined by Bruno Feitler -, this region was not excluded from the scope of action of Lisbon inquisitors, whose jurisdiction extended to include the Portuguese territories in the Atlantic world..$^{99}$

Novinsky and her students pursued traditional research about New Christians, the most affected victims of the Inquisition in Brazil, reviving topics and opening themselves to new suggestions, including, amongst others, the intriguing book about crypto-Jews in 
America by Nathan Wachtel. ${ }^{100}$ This was complemented, in diverse aspects, by the book in which Feitler examined North-Eastern Brazil between the $17^{\text {th }}$ and $18^{\text {th }}$ centuries, which provided a host of new leads even for the institutional history of the tribunal, as well as by the research carried out by Ricardo Escobar Quevedo about the innumerable Jewish converts of Portuguese origin who were captured by Spanish inquisitors in the New World.$^{101}$ In the meanwhile, however, from the late 1980s onwards, aspects of inquisitorial actions unrelated to crypto-Judaism have also gained prominence, albeit focusing especially on Brazilian colonial society. Ronaldo Vainfas used the sources of the Holy Office to penetrate the universe of an exuberant sexual life, a physical encounter between European settlers, Amerindians and Africans taken as slaves to Brazil. ${ }^{102} \mathrm{~A}$ few years later, the same author demonstrated the wealth of information available in these documents to study central aspects of the belief systems of colonised Amerindians, reconstructing the late- $16^{\text {th }}$ century anti-Portuguese revolt by the Santidade de Jaguaripe, which also incorporated indigenous millenarian concerns and the absorption of parts of the Catholic doctrine imparted by Jesuit missionaries. ${ }^{103}$

Inquisitorial papers have proved to be a first rate source to further study essential aspects of the centuries of Portuguese domination in Brazil, as well as the Spanish domination in vast tracts of the Americas. ${ }^{104}$ They have made it possible, for example, to reinterpret the history of cultural phenomena that are peculiar to an Atlantic world, which could appear to be an inferno (hell) for those who viewed it through the lens of demonology, but which also gave rise to unexpected and widespread behaviours of tolerance, as Stuart Schwartz has affirmed in a broad and controversial study conducted on the basis of Portuguese and Spanish inquisitorial archives. ${ }^{105}$

The dynamism of recent historiography about Brazil in the modern age developed on the basis of inquisitorial sources has also promoted new research about the organisation of the Holy Office's presence and, in more general terms, about aspects of institutional history, including the use of exile in Brazil as a penalty inflicted on specific categories of those who had been convicted. ${ }^{106}$ In addition to the aforesaid studies about the network of familiars by Buono Calainho and Wadsworth, the latter (in an article) and Feitler (in the first part of his book) have focused on the system of delegating inquisitorial powers and forms of collaborating with local clerics. ${ }^{107}$ The Jesuits also played a prominent role and there were no dearth of conflicts, such as the clash that resulted in the case against Father Manuel de Morães in the mid-1 $17^{\text {th }}$ century. ${ }^{108}$ Neglected after the classic monograph by Gonçalves Salvador, the southern regions also became the subject of research from an institutional point of view. ${ }^{109}$

The Inquisition undoubtedly had a less visible presence in the territories of the Portuguese empire in Africa than in Brazil. The tribunal never established there a stable headquarters but instead depended either on the Lisbon tribunal (North Africa, Atlantic Isles and settlements along the western shores of Africa) or on that of Goa (east coast of Africa). Although only a handful of isolated studies are available even today, the activities of the Portuguese Inquisition in Africa are beginning to gain prominence, due to the monograph by José Alberto Tavim about the settlements of Portuguese New Christians in Morocco, as well as the innovative essays edited by Bethencourt and Philip Havik in the proceedings of a conference that was held in 2003. ${ }^{110}$

40 The case of the Goa Inquisition is rather surprising. Only partially justified by the loss of almost all the documents pertaining to over 17,000 cases (although the invaluable lists mentioning the names of the accused, the dates of the cases, crimes and a brief summary 
of each case were fortunately saved), the lack of studies about the most bloody seat of the Portuguese Inquisition is in stark contrast to the historiography pertaining to Brazil. ${ }^{111}$ For some time now most historians have concentrated on the persecution of New Christians, who were the favourite target of the Holy office in India until the early 1580 s. This is the case with James Boyajian, while Ana Isabel Cannas da Cunha demonstrated to what extent the emergence of the Inquisition was due to the intention to export to India the persecution of the conversos who were fleeing from the Iberian Peninsula. ${ }^{112}$ The possibility of extracting data and information even from the limited archival material available about the Goa Inquisition has been amply demonstrated by the works by Tavim, especially in his book about the Jews and New Christians in Cochin, published in the same year in which Amiel wrote an essay summarising the nature of the Indian tribunal. ${ }^{113}$

41 Along with Anne Lima, Amiel also coordinated the elegant reprint of the celebrated Relation by Charles Dellon, with an introduction in which he highlighted the multiple objectives of the Inquisition in India : if, in fact, Jewish converts accounted for the highest number of death sentences, the Inquisition had a far vaster and more insidious impact on Indians, especially Hindus; the repression that the latter faced, as did neophytes of Muslim origin, other presumed heretics and even non-converts still awaits in-depth research. ${ }^{114}$ Much still remains to be studied, including the aspect of relations between inquisitors, bishops and missionaries. Feitler has already taken the initiative in this regard, with an article written on the basis of material about the Holy Office in Goa preserved at the National Library in Rio de Janeiro. ${ }^{115}$ The renewed interest in studies about the history of Portuguese colonialism, as well as about the religious backdrop against which it developed, will go a long way towards ensuring due recognition of the central role that this tribunal played in the history of the Inquisition in the Portuguese empire. Moreover, alongside a study of the Holy Office in Portugal itself, the institutional history of the Inquisition in the Portuguese empire can be examined using the most upto-date methodological proposals, so as to ensure an in-depth knowledge of the global impact that the Inquisition had on the extraordinary religious and cultural variety of its victims in the Portuguese world. ${ }^{116}$ After the preliminary groundwork by Caio Boschi, I have just concluded an essay that traces the emergence of a cohesive vision and the preparation of an overall strategy on the part of the authorities in Portugal for the diverse overseas territories where the Inquisition had a presence. My essay also reflects upon organisational models and forms of intervention and their circulation throughout the empire, often due to the services rendered by the missionaries. ${ }^{117}$

\section{Conclusions}

Although not bereft of significant gaps and reticence, modern historiography pertaining to the Portuguese Inquisition has made it possible to achieve a range of results and has produced new stimuli, thanks to approaches and indications in the field of research that are maturing and are increasingly capable of reducing the gap with regard to knowledge about the activities of the Holy Office in Spain and in Italy. Even a return to studies about the origins of the tribunal or its decline and abolition reveals a widespread awareness about the Inquisition as a well-defined historical object, albeit one that has undergone a constant evolution: an institution that had a beginning, an often tumultuous history during the three centuries of its existence and an end that occurred during an age that marked a fundamental shift in Portuguese history, from the Ancien Régime to the liberal 
age, inaugurating a turbulent phase in the nation's political life. ${ }^{118} \mathrm{~A}$ symbol of the watershed between the modern and the contemporary age, the abolition of a tribunal that had had a deep impact on the history of Portugal and its overseas empire marked the beginning of a new era, in which many social and moral conditions protected by the Inquisition were called into question. The Inquisition nonetheless left an enduring legacy in a country like Portugal, which even today has a strong Catholic identity.

Perhaps it is finally time to dare to set in motion a preliminary attempt to reconstruct a general overview of the history of the Holy Office in Portugal and its overseas empire between the $16^{\text {th }}$ and the $19^{\text {th }}$ centuries. Anyone who wishes to embark upon such an endeavour in the coming years will be able to avail of a wealth of studies and research, apart from the advantage of being able to access a centralised archive to clarify hitherto unexplored aspects. Scholars must be aware that they will only be able to proffer a partial glimpse of this history, without any pretensions of being an exhaustive guide, let alone an objective one. What is currently needed is an intelligent response to the pressing need for a general history of the Portuguese Inquisition, as exists in the case of the other two modern Inquisitions. One hopes that in the not too distant future it will be possible to peruse a first coherent narration, with a pondered equilibrium amongst the parts of the whole: a bold proposal for a global overview, aimed not so much at providing a systematic organisation of what is already known, thus confining the great energy of a historical subject like the Portuguese Inquisition to the pages of an elegant volume that will never leave library shelves, but rather at promoting new discussions and critiques, as also the emergence of explicit divergences. This is an inevitable outcome for a historiography that has consistently grown in recent decades and is now acknowledged to be of international importance, so that in the future it can move towards new and more penetrating questions.

\section{NOTES}

1. Juan Antonio Llorente, Histoire critique de l'Inquisition d'Espagne, 4 vols. (Paris : Treuttel \& Würtz, 1817-18; Spanish ed. 1822) ; Henry Charles Lea, A History of the Inquisition in Spain (New YorkLondon : Macmillan, 1906-07) ; Spanish trans. Historia de la Inquisición española, ed. Ángel Alcalá, 3 vols. (Madrid : Fundación Universitaria Española, 1983-84).

2. Henry Kamen, The Spanish Inquisition (London : Weidenfield \& Nicholson, 1965). The book was revised until its last edition in 1997. Beside Bartolomé Bennassar et al., L'Inquisition espagnole, $X V^{e}$ $X I X^{e}$ siècle (Paris : Hachette, 1979), I refer to Joaquín Pérez Villanueva (dir.), La Inquisición española. Nueva visión, nuevos horizontes (Madrid : Siglo XXI, 1980) ; Miguel Jiménez Monteserín, Introducción a la Inquisición española (Madrid : Editorial Nacional, 1981) ; Ángel Alcalá et al., Inquisición española y mentalidad inquisitorial (Barcelona : Ariel, 1984) ; Historia de la Inquisición en España y América, dir. Bartolomé Escandell Bonet y Joaquín Pérez Villanueva, 3 vols. (Madrid: Biblioteca de Autores Cristianos-Centro de Estudios Inquisitoriales, 1984-2000). I also call the attention to the highvalue methodological contribution made by studies on district tribunals, or on specific territorial areas: Ricardo García Cárcel, Orígenes de la Inquisición española. El tribunal de Valencia, 1478-1530 (Barcelona: Península, 1976); Id., Herejía y sociedad en el siglo XVI. La Inquisición en Valencia, 
1530-1609 (Barcelona : Península, 1980) ; Jaime Contreras, El Santo Oficio de la Inquisición en Galicia, 1560-1700. Poder, Sociedad, Cultura (Madrid : Akal, 1982) ; Richard H. Greenleaf, Inquisición y sociedad en el México colonial (Madrid : José Porrúa Turanzas, 1985) ; Jean-Pierre Dedieu, L'administration de la foi. L'Inquisition de Tolède, XVI ${ }^{e}$-XVIII ${ }^{e}$ siècle (Madrid: Casa de Velázquez, 1989) ; Stephen Haliczer, Inquisition and Society in the Kingdom of Valencia, 1478-1834 (Berkeley : University of California Press, 1990); William Monter, Frontiers of Heresy. The Spanish Inquisition from the Basque Lands to Sicily (Cambridge : Cambridge University Press, 1990).

3. Jaime Contreras, Historia de la Inquisición española, 1478-1834: herejías, delitos y representación (Madrid: Arco Libros, 1997); John Edwards, The Spanish Inquisition (Stroud-Charleston, SC: Tempus, 1999) ; Ricardo García Cárcel-Doris Moreno Martínez, Inquisición. Historia crítica (Madrid : Temas de Hoy, 2000) ; Helen Rawlings, The Spanish Inquisition (Malden, MA : Blackwell, 2006). On the trends of current research see Kimberly Lynn Hossain, 'Unraveling the Spanish Inquisition : Inquisitorial Studies in the Twenty-First Century', History Compass 5 (2007), 1280-93.

4. Andrea Del Col, L'Inquisizione in Italia. Dal XII al XXI secolo (Milano : Mondadori, 2006).

5. Adriano Prosperi, Tribunali della coscienza. Inquisitori, confessori, missionari (Torino: Einaudi, 1996). 'It seems that the time is quickly drawing near when the availability of sources and detailed preliminary studies will make possible a critical treatment of our subject' : I quote from John Tedeschi, Il giudice e l'eretico. Studi sull'Inquisizione romana (Milano : Vita e Pensiero, 1997), 11. 6. Giovanni Romeo, L'Inquisizione nell'Italia moderna (Roma-Bari : Laterza, 2002); Christopher F. Black, The Italian Inquisition (New Haven and London : Yale University Press, 2009).

7. Dizionario storico dell'Inquisizione, dir. Adriano Prosperi con la collaborazione di Vincenzo Lavenia e John Tedeschi, 4 vols. (Pisa : Edizioni della Normale, 2010). It is a tool that promises to stand together works like Emil van der Vekene, Bibliotheca Bibliographica Historiae Sanctae Inquisitionis, 3 vols. (Vaduz : Topos Verlag, 1982-92) ; Index des livres interdits, dir. J.M. De Bujanda, 11 vols. (Sherbrooke : Centre d'Études de la Renaissance ; Genève : Librairie Droz, 1984-2000); The Italian Reformation of the Sixteenth Century and the Diffusion of Renaissance Culture. A Bibliography of the Secondary Literature, ca. 1750-1997, compiled by John Tedeschi in association with James M. Lattis, with an historiographical introduction by Massimo Firpo (Modena: Franco Cosimo Panini ; Ferrara : ISR, 2000). For the proceedings of conferences hosted in Italy, see L'Inquisizione romana in Italia nell'età moderna. Archivi, problemi di metodo e nuove ricerche. Atti del seminario internazionale, a cura di Andrea Del Col e Giovanna Paolin (Roma : Ministero per i beni culturali e ambientali, 1991) ; L'Inquisizione e gli ebrei in Italia, a cura di Michele Luzzati (Roma-Bari : Laterza, 1994); L'Inquisizione e gli storici: un cantiere aperto (Roma: Atti dei Convegni Lincei, 2000); L'Inquisizione romana: metodologia delle fonti e storia istituzionale. Atti del seminario internazionale, a cura di Andrea Del Col e Giovanna Paolin (Trieste : Università di Trieste ; Montereale Valcellina : Circolo culturale Menocchio, 2000) ; Inquisizioni : percorsi di ricerca, a cura di Giovanna Paolin (Trieste: Università di Trieste, 2001); L'Inquisizione. Atti del simposio internazionale, a cura di Agostino Borromeo (Città del Vaticano: Biblioteca Apostolica Vaticana, 2003); Le inquisizioni cristiane e gli Ebrei (Roma : Atti dei Convegni Lincei, 2003); A dieci anni dall'apertura dell'archivio della Congregazione per la Dottrina della Fede: storia e archivi dell'Inquisizione (Roma: Atti dei Convegni Lincei, 2010) [in press].

8. Jean-Pierre Dedieu-René Millar Carvacho, 'Entre histoire et mémoire. L'Inquisition à l'époque moderne : dix ans d'historiographie', Annales HSS 57 (2002), 349-72.

9. Adriano Prosperi, 'L'Inquisizione. Verso una nuova immagine ?', in Id., L'Inquisizione romana : letture e ricerche (Roma : Edizioni di Storia e Letteratura, 2003), 3-27.

10. However, historians of the Portuguese Inquisition paid some attention to a few essays in Bennassar, L'Inquisition espagnole : Jean-Pierre Dedieu, 'Les quatre temps de l'Inquisition', 15-41, is recovered by Joaquim Romero Magalhães, 'La Inquisición portuguesa : intento de periodización', Revista de Historia de la Inquisición 2 (1992), 71-93; Bartolomé Bennassar, 'L’Inquisition ou la pédagogie de la peur', 105-41, by Maria José Ferro Tavares, 'Inquisição : um compellere intrare ou 
uma catequização pelo medo (1536-1547)' Revista de História Económica e Social 21 (1987), 1-28. The latter seems to suffer from interpretative rigidity, as I mantained in my 'Catequização pelo medo? Inquisitori, vescovi e confessori di fronte ai nuovi cristiani nel Portogallo del Cinquecento', in Le inquisizioni cristiane e gli Ebrei, 123-93.

11. It is proved even by the only attempt of a general overview, albeit divulgative : António Baião, Episódios dramáticos da Inquisição portuguesa, 3 vols. (Lisboa : Seara Nova, 1972-73³ ; or. ed. 1919-38). 12. Alexandre Herculano, História da origem e estabelecimento da Inquisição em Portugal, introd. Jorge Borges de Macedo, 3 vols. (Lisboa : Livraria Bertrand, 1975-76), 1:11. I quote from the English ed. : History of the Origin and Establishment of the Inquisition in Portugal, trans. John C. Branner, prolegomenon by Yosef Hayim Yerushalmi (New York : Ktav Publishing House, 1972), 68.

13. Ludwig von Pastor, 'Allgemeine Dekrete der Römischen Inquisition aus den Jahren 1555-1597', Historisches Jahrbuch der Görres-Gesellschaft 33 (1912), 479-549. The pages devoted by Lea to the Portuguese Inquisition are illuminating : A History of the Inquisition in Spain, 3:235-90.

14. António Baião published several articles on the Portuguese tribunal. Those which appeared in the Archivo Historico Portuguez from 1906 onwards were later collected in A Inquisição em Portugal e no Brasil. Subsidios para a sua Historia (Lisboa : Edições do Arquivo Histórico Português, 1920).

15. João Lúcio de Azevedo, História dos Christãos Novos Portugueses (Lisboa : Livraria Clássica, 1921). 16. Marcel Bataillon, Études sur le Portugal au temps de l'humanisme (Paris: Fundação Calouste Gulbenkian-Centro Cultural Português, 1974²); Mário Brandão, A Inquisição e os professores do Colégio das Artes, 2 vols. (Coimbra: Universidade de Coimbra, 1948-69); José Sebastião da Silva Dias, Correntes de sentimento religioso em Portugal (Coimbra : Instituto de Estudos Filosóficos, 1960) ; Id., O primeiro rol de livros proibidos (Coimbra : Faculdade de Letras, 1963) ; Id., A política cultural da época de D. João III (Coimbra : Imprensa da Universidade, 1969).

17. Israël-Salvator Révah worked both on the control of the books and on marranism. Among his writings, see 'Les Marranes', Revue des Études Juives 118 (1959-60), 29-77 ; La censure inquisitoriale portugaise au XVI siècle (Lisboa: Instituto de Alta Cultura, 1960); and the collected essays Études Portugaises, publiées par les soins de Charles Amiel (Paris : Fundação Calouste Gulbenkian-Centro Cultural Português, 1975) ; Des marranes à Spinoza, textes réunis par Henry Méchoulan, PierreFrançois Moreau et Carsten L. Wilke (Paris: Vrin, 1995); Uriel da Costa et les marranes de Porto. Cours au Collège de France, 1966-1972, édition par Carsten L. Wilke (Paris : Centre Culturel Calouste Gulbenkian, 2004).

18. Cecil Roth, A History of the Marranos (Philadelphia : Jewish Publication Society of America, 1932) ; Yosef Hayim Yerushalmi, From Spanish Court to Italian Ghetto. Isaac Cardoso : a Study in Seventeenth-Century Marranism and Jewish Apologetics (New York : Columbia University Press, 1971). 19. The dispute that followed the publication of the volume Inquisição and Cristãos-Novos (Porto: Inova, 1969) by António José Saraiva was hosted by the newspaper Diário de Lisboa in 1971. The articles can be found in the appendix of Saraiva's book from its $5^{\text {th }}$ edition onwards (Lisboa: Estampa, 1985). Recently, an English revised edition has been published: Marrano Factory. The Portuguese Inquisition and its New Christians, 1536-1756, ed. Herman P. Salomon and I.S.D. Sassoon (Leiden-Boston : Brill, 2001).

20. José Gonçalves Salvador, Cristãos-novos, jesuítas e Inquisição. Aspectos da sua actuação nas Capitanias do Sul, 1530-1680 (São Paulo : Livraria Pioneira, 1969) ; Anita Novinsky, Cristãos-novos na Bahia (São Paulo : Perspectiva, 1972).

21. Examples can be traced back to Herman P. Salomon's reaction to the introduction by Yerushalmi to Herculano's English edition (1972), both in the review of the book published in The Journal of the American Portuguese Cultural Society 6-7 (1972-73), 59-65 ; 68-75, and in the short essay Novos Pontos de vista sobre a Inquisição em Portugal (Porto : Athena, 1976).

22. José Sebastião da Silva Dias, 0 erasmismo e a Inquisição em Portugal. 0 processo de Fr. Valentim da Luz (Coimbra : Imprensa da Universidade, 1975). 
23. Gustav Henningsen, 'El 'banco de datos' del Santo Oficio. Las relaciones de causas de la Inquisición española (1550-1700)', Boletín de la Real Academia de la Historia 174 (1977), 547-70.

24. Charles Amiel, 'Les archives de l'Inquisition portugaise. Regards et réflexions', Arquivos do Centro Cultural Português 14 (1979), 421-43. The essay was subsequently published in the proceedings of the Danish symposium: 'The Archives of the Portuguese Inquisition: a Brief Survey', in The Inquisition in Early Modern Europe. Studies on Sources and Methods, ed. Gustav Henningsen and John Tedeschi in Association with Charles Amiel (Dekalb, IL : Northern Illinois University Press, 1986), 79-99.

25. Gustav Henningsen, 'Inquisition and Interdisciplinary History. Report from an International Symposium on the Medieval and Modern Inquisition, Skjoldenæsholm, 5th-9th September 1978', Temenos 15 (1979), 119-25. I quote from p. 119.

26. John Tedeschi, 'Preliminary Observation on Writing a History of the Roman Inquisition' [1979], in Id., The Prosecution of Heresy. Collected Studies on the Inquisition in Early Modern Italy (Binghamton: Center for Medieval and Early Renaissance Studies, 1991), 4.

27. Gustav Henningsen, 'The Database of the Spanish Inquisition. The relaciones de causas-Project Revisited', in Vorträge zur Justizforschung. Geschichte und Theorie, hrsg. Heinz Mohnhaupt und Dieter Simon, 2 vols. (Frankfurt am Main : Klostermann, 1992-93), 2:43-85.

28. Among the most relevant contributions, see Isaías da Rosa Pereira, Documentos para a História da Inquisição em Portugal (século XVI) (Lisboa: Cáritas portuguesa, 1987); Id., A Inquisição em Portugal, séculos XVI-XVII. Período filipino (Lisboa : Vega, 1993).

29. Id., 'O processo de Guilherme de Mascot, bretão marceiro, na Inquisição de Lisboa, 1562-1563', Revista da Faculdade de Letras da Universidade de Lisboa s. 4, 1 (1977), 557-98 ; Id., 'Um francês do Languedoque na Inquisição de Lisboa : Guilherme Bro, clérigo de missa, 1553-1555', in Actas das III Jornadas de Arqueologia, 2 vols. (Lisboa: Associação dos Arqueólogos Portugueses, 1978-79), 1:423-51. See also the late 'O processo de Manuel de Travaços na Inquisição de Lisboa (1570-1571) e a prisão de Damião de Góis’, Anais da Academia Portuguesa da História 36 (1998), 157-73.

30. José Pedro Paiva, “ "Católico sou e não luterano”. o processo de Damião de Góis na Inquisição (1571-1572)', in Damião de Góis. Um humanista na Torre do Tombo, coord. José Vicente Serrão (Lisboa: IANTT, 2002), 20-42 ; Isabel Drumond Braga, Os estrangeiros e a Inquisição portuguesa (Lisboa : Hugin, 2002).

31. Inventário dos processos da Inquisição de Coimbra, 1541-1820, leit. e introd. Luís de Bivar Guerra, 2 vols. (Paris : Fundação Calouste Gulbenkian-Centro Cultural Português, 1972) ; José Veiga Torres, 'Uma longa guerra social : os ritmos da repressão inquisitorial em Portugal', Revista de História Económica e Social 1 (1978), 55-68.

32. José do Nascimento Raposo, 'Social characteristic of those accused before the Coimbra Inquisition', Revue des Études Juives 141 (1982), 201-17 ; José Veiga Torres, 'Uma longa guerra social : novas perspectivas para o estudo da Inquisição portuguesa. A Inquisição de Coimbra', Revista de História das Ideias 8 (1986), 56-70.

33. José Veiga Torres, 'Da repressão religiosa para a promoção social. A Inquisição como instância legitimadora da promoção social da burguesia mercantil', Revista Crítica de Ciências Sociais 40 (1994), 109-35. An essay that does not conform to this model is Sônia A. Siqueira, A Inquisição portuguesa e a sociedade colonial (São Paulo : Ática, 1978).

34. Joaquim Romero Magalhães, 'E assim se abriu judaismo no Algarve', Revista da Universidade de Coimbra 29 (1981), 1-74. For an attempt of periodization see Id., "Em busca dos "tempos" da Inquisição (1573-1615)', Revista de História das Ideias 9:2 (1987), 191-228.

35. Francisco Bethencourt, 'Campo religioso e Inquisição em Portugal no século XVI', Estudos Contemporâneos 6 (1984), 43-60.

36. Raul Rêgo, Os Índices expurgatórios e a cultura portuguesa (Lisboa : Ministério da Educação e das Universidades, 1982) ; Índices dos livros proibidos em Portugal no século XVI, ed. Artur Moreira de Sá (Lisboa: INIC, 1983). It is valuable also De Bujanda (dir.), Index des livres interdits, 4 : Index de 
l'Inquisition portugaise. 1547, 1551, 1561, 1564, 1581 (Sherbrooke : Centre d'Études de la Renaissance, Genève ; Librairie Droz, 1994). On $17^{\text {th }}$ century episodes see Herman P. Salomon, Portrait of a New Christian Fernão Álvares Melo, 1569-1632, with contributions by J. de Lange (Paris: Fundação Calouste Gulbenkian-Centro Cultural Português, 1982) ; James C. Boyajian, Portuguese Bankers at the Court of Spain, 1626-1650 (New Jersey: Rutgers University Press, 1983) ; Elvira Cunha de Azevedo Mea, '1621-1634. Coimbra : o sagrado e o profano em choque', Revista de História das Ideias 9:2 (1987), 229-48. Has yet to be surpassed the essay by Raul Rêgo, 'O Marquês de Pombal, os cristãos-novos e a Inquisição', in Maria Helena Carvalho dos Santos (ed.), Pombal revisitado (Lisboa : Estampa, 1984), 309-36.

37. Inquisição. Comunicações apresentadas ao $1^{\circ}$. Congresso Luso-Brasileiro sobre Inquisição, coord. Maria Helena Carvalho dos Santos, 3 vols. (Lisboa : Universitária Editora-Sociedade Portuguesa de Estudos do Século XVIII, 1989-1990). I quote from 1:15-6; Inquisição. Ensaios sobre mentalidade, heresias e arte, orgs. Anita Novinsky e Maria Luiza Tucci Carneiro (Rio de Janeiro: Expressão e Cultura ; São Paulo : Edusp, 1992).

38. Maria José Ferro Tavares, Judaísmo e Inquisição. Estudos (Lisboa : Estampa, 1987). Beside several articles, see Los Judíos en Portugal (Madrid: Mapfre, 1992). A different line of research was followed by Elias Lipiner, o Sapateiro de Trancoso e o Alfaiate de Setúbal (Rio de Janeiro: Imago, 1993) ; Id., Os Baptizados em Pé. Estudos acerca da origem e da luta dos cristãos novos em Portugal (Lisboa : Vega, 1998).

39. Francisco Bethencourt, $O$ imaginário da magia : feiticeiras, saludadores e nigromantes no século XVI (Lisboa : Universidade Aberta, 1987); Id., 'Inquisição e controle social', História \& Crítica 14 (1987), 5-18.

40. António Borges Coelho, Inquisição de Évora. Dos primórdios a 1668, 2 vols. (Lisboa : Caminho, 1987).

41. Charles Amiel, 'Inquisitions modernes : le modèle portugais', in Histoire du Portugal, histoire européenne. Actes du colloque (Paris : Fondation Calouste Gulbenkian-Centre Culturel Portugais, 1987), 43-58.

42. On sources and archives see Maria do Carmo Jasmins Dias Farinha, Os Arquivos da Inquisição (Lisboa: IANTT, 1990); Francisco Bethencourt, 'Les sources de l'Inquisition portugaise: évaluation critique et méthodes de recherche', in L'Inquisizione Romana in Italia, 357-67.

43. António Baião, A Inquisição de Goa, 2 vols. (Lisboa : Academia das Ciências, 1930-45).

44. Francisco Bethencourt, História das Inquisições. Portugal, Espanha, Itália (Lisboa: Círculo de Leitores, 1994). Few works about the Inquisition knew the same number of translations : into French in 1995 ; into Spanish in 1997. More recently, into English : The Inquisition. A Global History, 1478-1834 (Cambridge : Cambridge University Press, 2009).

45. Some of the aspects which Bethencourt focused on had been the object of other studies. See Consuelo Maqueda Abreu, El Auto de Fe (Madrid: Istmo, 1992); Miguel Jiménez Monteserín, 'Modalidades y sentido histórico del Auto de Fe', in Escandell Bonet-Pérez Villanueva (eds.), Historia de la Inquisición, 2:559-87 ; or, concerning the inquisitorial correspondance system, Guido Dall'olio, 'I rapporti tra la Congregazione del Sant'Uffizio e gli inquisitori locali nei carteggi bolognesi (1573-1594)', Rivista Storica Italiana 105 (1993), 246-86.

46. Elvira Cunha de Azevedo Mea, A Inquisição de Coimbra no Século XVI. A Instituição, os Homens e a Sociedade (Porto : Fundação Eng. António de Almeida, 1997).

47. Paulo Drumond Braga, A Inquisição nos Açores (Ponta Delgada : Instituto Cultural, 1997).

48. Michèle Janin-Thivos Tailland, Inquisition et société au Portugal. Le cas du tribunal d'Évora, 1660-1821 (Paris : Centre Culturel Calouste Gulbenkian, 2001).

49. Maria do Carmo Teixeira Pinto, Os cristãos-novos de Elvas no reinado de D. João IV : heróis ou antiheróis? (Ph.D. diss., Lisboa: Universidade Aberta, 2003); Claude B.Stuczynski, A 'Marrano Religion'? The Religious Behavior of the New Christians of Bragança convicted by the Coimbra Inquisition 
in the Sixteenth Century (1541-1605) [in Hebrew], 2 vols. (Ph.D. diss, Ramat Gan : Bar Ilan University, 2005).

50. After Romero Magalhães' article about the Algarve (mentioned in footnote 34), many articles were dedicated to single inquisitorial visits. The best is José Pedro Paiva, 'As entradas da Inquisição, na vila de Melo, no século XVIII : pânico, integração/segregação, crenças e desagregação social', Revista de História das Ideias 25 (2004), 169-208.

51. The complete series of the Lisbon trials is under digitalization in order to make them available on the webpage of TT online project (<http://ttonline.dgarq.gov.pt/>)

52. A number of studies on a regional scale followed the article by Miguel Echeverría GoicoecheaPilar García de Yébenes Prous-Rafael De Lera García, 'Distribución y número de los familiares del Santo Oficio en Andalucía durante los siglos XVI-XVIII', Hispania Sacra 39 (1987), 59-94. See the synthesis by Gonzalo Cerrillo Cruz, Los familiares de la Inquisición española (Valladolid : Consejería de Educación y Cultura, 2000).

53. Habilitações para o Santo Ofício, 25 : S-Z, ed. António de Assis-Maria Graça de Araújo da RochaLuís Soveral Varella (Lisboa : Manuel Abranches de Soveral, 2003).

54. Daniela Buono Calainho, Agentes da fé: familiares da Inquisição portuguesa no Brasil colonial (Bauru: Edusc, 2006) ; James E. Wadsworth, Agents of Orthodoxy. Honor, Status and the Inquisition in Colonial Pernambuco, Brazil (Lanham, MD : Rowman and Littlefield, 2007).

55. Bethencourt, História das Inquisições, 91-3 ; James E. Wadsworth, 'Celebrating St. Peter Martyr. The Inquisitional Brotherhood in Colonial Brazil', Colonial Latin American Historical Review, 12:2 (2003), 173-227 ; Georgina Silva dos Santos, A Irmandade de São Jorge e a Inquisição na Lisboa moderna (Lisboa : Colibri-Instituto de Cultura Ibero-Atlântica, 2005).

56. The state of art about the Portuguese Inquisition is radically different than about the Spanish one. However, it has similarities to the bibliography about the Roman Holy Office, whose central Congregation has yet to be investigated, while only one biography of a cardinal prefect exists : Saverio Ricci, Il sommo inquisitore. Giulio Antonio Santori tra autobiografia e storia, 1532-1602 (Roma : Salerno, 2002). Studies on the General Council of the Portuguese Inquisition lack too, with the exception of Maria do Carmo Jasmins Dias Farinha, 'A primeira visita do Conselho Geral à Inquisição de Lisboa', Cadernos de História Crítica 1 (1988), 5-59. An attempt to reconstruct biographies of inquisitors-general is to be found in Francisco Caeiro, 0 Arquiduque Alberto de Áustria vice-rei e Inquisidor-mor de Portugal, cardeal legado do Papa, governador e depois soberano dos Paises Baixos : história e arte (Lisboa, 1961), 245-87 ; Manuel Pereira Gonçalves, ‘O Franciscano Frei Diogo da Silva (1485-1541). Primeiro Inquisidor Geral do Reino de Portugal', Itinerarium 35 (1989), 67-91 ; Maria Luisa Braga, A Inquisição em Portugal, primeira metade do séc. XVIII. O Inquisidor geral D. Nuno da Cunha de Athayde e Mello (Lisboa: INIC, 1992). Several books were devoted to the powerful Cardinal Infant Dom Henrique, inquisitor-general from 1539 to 1578, but they dealt superficially with his inquisitorial office. The Dizionario storico dell'Inquisizione might fill the gaps for both the Roman and the Portuguese Inquisition with entries on central structures and offices. 57. It is available only a list elaborated by Maria do Carmo Jasmins Dias Farinha, 'Ministros do Conselho Geral do Santo Ofício', Memória 1 (1989), 101-63.

58. Partly published in modern editions -in the appendix of Baião, A Inquisição em Portugal, doc. 31 , or in single volumes, as the ones edited by Raul Rêgo, 0 último Regimento da Inquisição portuguesa (Lisboa : Excelsior, 1971) and 0 último Regimento e o Regimento da economia da Inquisição de Goa (Lisboa: Biblioteca Nacional de Lisboa, 1983)-, a complete collection of the general regulations can be found in Sônia A. Siqueira, 'Os Regimentos da Inquisição', Revista do Instituto Histórico e Geográfico Brasileiro 157 (1996), 495-1020; and in José Eduardo Franco-Paulo de Assunção, As metamorfoses de um polvo. Religião e política nos Regimentos da Inquisição portuguesa, séc. XVI-XIX (Lisboa: Prefácio, 2004), on which see the severe review by José Pedro Paiva in Lusitania Sacra s. 2, 17 (2005), 547-57. For a study see António Vasconcelos de Saldanha, Do Regimento da Inquisição portuguesa : notas sobre fontes de direito, in Inquisição. Ensaios, 97-115. 
59. Herman P. Salomon, 'The 'Monitório do Inquisidor Geral' of 1536. Background and Sources of some 'Judaic' Customs Listed therein', Arquivos do Centro Cultural Português 17 (1982), 41-64; Charles Amiel, 'Crypto-judaïsme et Inquisition. La matière juive dans les édits de la foi des Inquisitions ibériques', Revue de l'histoire des religions, 210 (1993), 145-68.

60. For a more extensive attempt see Elvira Cunha de Azevedo Mea, 'O Santo Ofício português. Da legislação à prática', in Mémorial I.-S. Révah. Études sur le marranisme, l'hétérodoxie juive et Spinoza, éd. par Henry Méchoulan et Gérard Nahon (Paris : Collection de la Revue des Études Juives ; Louvain : Peeters, 2001), 53-64. On the individual testimonies see Ana Isabel López-Salazar Codes, " "Che si riduca al modo di procedere di Castiglia ». El debate sobre el procedimiento inquisitorial portugués en tiempo de los Austrias', Hispania Sacra, 59 (2007), 243-68 ; and Bruno Feitler, 'Da 'prova' como objeto de análise da praxis inquisitorial : o problema dos testemunhos singulares no Santo Ofício português', in História do Direito em perspectiva. Do Antigo Regime à Modernidade, orgs. Ricardo Marcelo Fonseca e Airton Cerqueira Leite Seelaender (Curitiba : Juruá, 2008), 305-14. Yet there is a great distance between the bibliography pertaining to the Portuguese Inquisition and works like José Antonio Escudero (ed.), Perfiles jurídicos de la Inquisición española (Madrid : Instituto de Historia de la Inquisición-Universidad Complutense de Madrid, 1989). About the proceedings of the Portuguese Inquisition, I don't agree with Nathan Wachtel when he describes it as a court where 'individual errors dissolved within the bureaucratic machine working as a totality' ( $\mathrm{La}$ logique des bûchers (Paris : Seuil, 2009), 254).

61. For the Spanish Inquisition see Roberto López Vela, 'Inquisición y monarquía : estado de la cuestión (1940-1990)', Hispania 176 (1990), 1123-40. It is a central issue in the research of José Martínez Millán. See, for instance, the volume he edited, Felipe II (1527-1598). Europa y la monarquía católica, 3 : Inquisición, religión y confesionalismo (Madrid: Perteluz, 1998); and his overview La Inquisición española (Madrid : Alianza, 2007).

62. António Manuel Hespanha, Vísperas del Leviatán. Instituciones y poder político : Portugal, siglo XVII , trans. Fernando J. Bouza Álvarez (Madrid: Taurus, 1989 ; Portuguese ed. Coimbra: Almedina, 1994).

63. Paolo Prodi, Una storia della giustizia. Dal pluralismo dei fori al moderno dualismo tra coscienza e diritto (Bologna: Il Mulino, 2000). Among the first reactions see the review by Adriano Prosperi, 'Una discussione con Paolo Prodi', Storica 17 (2000), 85-100 ; and the book by Vincenzo Lavenia, L'infamia e il perdono. Tributi, pene e confessione nella teologia morale della prima età moderna (Bologna : Il Mulino, 2004). Finally, see Adriano Prosperi, 'Storia dell'Inquisizione come storia della giustizia', Studia Borromaica 23 (2009), 43-52.

64. First of all, the Ph.D. dissertation by Ana Isabel López-Salazar Codes, Poder y ortodoxia. El gobierno del Santo Oficio en el Portugal de los Austrias, 1578-1653 (Ciudad Real: Universidad de Castilla-La Mancha, 2008). She is among the few scholars of Portuguese Inquisition who discuss Hespanha's works.

65. Giuseppe Marcocci, I custodi dell'ortodossia. Inquisizione e Chiesa nel Portogallo del Cinquecento (Roma : Edizioni di Storia e Letteratura, 2004), 87-9, 338-9.

66. Azevedo, História dos Christãos Novos, 241-64 ; António Borges Coelho, A Inquisição e os seus fantasmas: a morte de um inquisidor geral, in Inquisição Portuguesa. Tempo, Razão e Circunstância, coord. Luís Filipe Barreto et al. (Lisboa-São Paulo : Prefácio, 2007), 7-19.

67. Luís A. de Oliveira Ramos, 'A Inquisição pombalina', in Como interpretar Pombal ? No bicentenário da sua morte, in Broteria 115 (1982), 170-180.

68. Works like the ones by José Martínez Millán for Spain -La Hacienda de la Inquisición, 1478-1700 (Madrid: Instituto Enrique Flórez-CSIC, 1984)- and Vincenzo Lavenia for Italy -'I beni dell'eretico, i conti dell'inquisitore. Confische, stati italiani, economia del Sant'Uffizio', in L'Inquisizione e gli storici, 47-94- don't exist in the case of the Portuguese Inquisition. But the article by Sônia Â. Siqueira, 'A Inquisição e os confiscos', Revista de História 40 (1970), 323-40, is less isolate after José Veiga Torres, ‘A vida financeira do Conselho Geral do Santo Ofício da 
Inquisição (séculos XVI-XVIII)', Notas Económicas 2 (1993), 24-39; and Maria Leonor da Cruz, 'Relações entre poder real e Inquisição (séculos XVI-XVII). Fontes de renda, realidade social e política financeira', in Inquisição Portuguesa. Tempo, 107-26.

69. Stand out António Manuel Rodrigues, 'A Universidade e a Inquisição', in História da Universidade em Portugal (Coimbra: Imprensa da Universidade de Coimbra; Lisboa: Fundação Calouste Gulbenkian, 1997), 1/2:971-88; and Maria Teresa Esteves Payan Martins, A censura literária em Portugal nos séculos XVII e XVIII (Lisboa : Fundação Calouste Gulbenkian-FCT, 2005).

70. Roberto Rowland, 'L'Inquisizione portoghese e gli ebrei', in L'Inquisizione e gli ebrei, 66. I followed his suggestion in my article 'Questioni di stile. Gastão de Abrunhosa contro l'Inquisizione portoghese (1602-1607)', Studi Storici 48 (2007), 779-815.

71. Elvira Cunha de Azevedo Mea, 'A resistência sefardita ao Santo Ofício no período filipino', Cadernos de Estudos Sefarditas 2 (2002), 47-58.

72. Charles Amiel, 'Os Cárceres de Vigia da Inquisição Portuguesa', in Ibéria Judaica : Roteiros da Memória, orgs. Anita Novinsky-Diane Kuperman (Rio de Janeiro : Expressão e Cultura ; São Paulo : Edusp, 1996), 141-50.

73. On the purity of blood there isn't a historiographic tradition as for Spain, from the classic book by Albert A. Sicroff, Les controverses des statuts de pureté de sang en Espagne du XVe au XVII siècle (Paris : Didier, 1969), to the article by Charles Amiel, 'La pureté de sang en Espagne', Annales du CESERE 6 (1983), 27-45. However, one can useful read Maria Luiza Tucci Carneiro, Preconceito Racial em Portugal e Brasil Colônia. Os Cristãos-Novos e o Mito da Pureza do Sangue (São Paulo: Perspectiva, 2005³ ; or. ed. 1983); and Fernanda Olival, 'Rigor e interesses: os estatutos de limpeza de sangue em Portugal', Cadernos de Estudos Sefarditas 4 (2004), 151-82.

74. João Manuel Andrade, Confraria de S. Diogo. Judeus secretos na Coimbra do século XVII (Lisboa : Nova Arrancada, 1999) ; Juan Ignacio Pulido Serrano, Os Judeus e a Inquisição no Tempo dos Filipes (Lisboa: Campo da Comunicação, 2007); Ana Maria Homem Leal de Faria, "Uma "teima" : do confronto de poderes ao malogro da reforma do Tribunal do Santo Ofício. A suspensão da Inquisição portuguesa (1674-1681)', in Inquisição Portuguesa. Tempo, 77-105.

75. Isabel M.R.M Drumond Braga, Mouriscos e cristãos no Portugal quinhentista. Duas culturas e duas concepções religiosas em choque (Lisboa: Hugin, 1999) ; José Alberto R.S. Tavim, 'Educating the Infidels within: Some Remarks on the College of the Cathecumens of Lisbon (XVIXVII centuries)', Annali della Scuola Normale Superiore di Pisa. Classe di Lettere e Filosofia s. 5, 1 (2009), 445-72. See also the Ph.D. dissertation by Rogério de Oliveira Ribas, Filhos de Mafoma. Mouriscos, cripto-islamismo e Inquisição no Portugal quinhentista, 2 vols. (Lisboa : Universidade de Lisboa, 2004). For a preliminary work on the renegades see Isabel M.R.M. Drumond Braga, Entre a Cristandade e o Islão (séculos XV-XVII). Cativos e renegados nas franjas de duas sociedades em confronto (Ceuta: Instituto de Estudios Ceutíes, 1998).

76. José Pedro Paiva, Bruxaria e superstição num país sem "caça às bruxas", 1600-1774 (Lisboa: Notícias, 1997). Among recent studies see Timothy D. Walker, Doctors, Folk Medicine and the Inquisition. The Repression of Magical Healing in Portugal during the Enlightenment (Leiden-Boston: Brill, 2005). For an overview of the current knowledge see José Pedro Paiva, 'Inquisizione e stregoneria in Portogallo nella prima età moderna', in Dinora Corsi-Matteo Duni (eds.), 'Non lasciar vivere la malefica'. Le streghe nei trattati e nei processi, secoli XIV-XVII (Firenze: Firenze University Press, 2008), 115-27.

77. Plinio Freire Gomes, Um herege vai ao Paraíso. Cosmologia de um ex-colono condenado pela Inquisição, 1680-1744 (São Paulo: Companhia das Letras, 1997); António Ribeiro, Um buraco no Inferno. João Pinto, o lavrador heresiarca, e a Inquisição (Coimbra : Palimage, 2006).

78. Pedro Vilas Boas Tavares, Beatas, inquisidores, teólogos. Reacção portuguesa a Miguel de Molinos (Porto: Centro Inter-Universitário de História da Espiritualidade, 2005). The book follows the recent study about Italy by Adelisa Malena, L'eresia dei perfetti. Inquisizione romana ed esperienze mistiche nel Seicento italiano (Roma: Edizioni di Storia e Letteratura, 2003). It is noteworthy also 
the essay by Laura de Mello e Souza, 'Entre o êxtase e o combate : visionárias portuguesas do século XVII', in Inquisição. Ensaios, 762-84.

79. Isabel Drumond M.R.M. Braga, A bigamia em Portugal na época moderna. Sentir mal do sacramento do matrimónio ? (Lisboa: Hugin, 2003). On the persecution of sodomy see Luiz Mott, 'Justitia et Misericordia : a Inquisição Portuguesa e a Repressão ao Nefando Pecado de Sodomia', in Inquisição. Ensaios, 703-38; for a study about the connection with the converso problem see Id., 'Filhos de Abrãao e de Sodoma. Cristãos-novos homosexuais nos tempos da Inquisição', in Ensaios sobra a intolerância. Inquisição, marranismo e anti-semitismo (homenagem a Anita Novinsky), orgs. Lina Gorenstein-Maria Luiza Tucci Carneiro (São Paulo : Humanitas, 2002), 23-63. All these works came after Rafael Carrasco, Inquisición y represión sexual en Valencia: historia de los sodomitas, 1565-1785 (Barcelona : Laertes, 1986) and Francisco Tomás y Valiente et al., Sexo barroco y otras transgresiones premodernas (Madrid: Alianza, 1990), which marked a turning point in the studies on early modern sexuality in the Iberian Peninsula. They were followed by analyses pertaining to the Spanish Inquisition, as Adelina Sarrión Mora, Sexualidad y confesión. La solicitación ante el tribunal del Santo Oficio, siglos XVI-XIX (Madrid: Alianza, 1994) and Stephen Haliczer, Sexuality in the Confessional : a Sacrament Profaned (New York: Oxford University Press, 1996). The first trials for soliciting in Portugal were analysed by Marcocci, I custodi dell'ortodossia, pp. 311-35; for an overall view see the master's dissertation by Jaime Ricardo Teixeira Gouveia, O Sagrado e o Profano em Choque no Confessionário. O Delito de Solicitação no Tribunal da Inquisição. Portugal, 1550-1700 (Coimbra : Universidade de Coimbra, 2006).

80. Fortunato de Almeida, História da Igreja em Portugal, 4 vols. (Porto: Portucalense; Lisboa : Livraria Civilização, 1968-1971² ; or. ed. 1910-1921), 2:421. Beside Prosperi's monograph, see the previous articles by Agostino Borromeo, 'Contributo allo studio dell'Inquisizione e dei suoi rapporti con il potere episcopale nell'Italia spagnola del Cinquecento', Annuario dell'Istituto storico italiano per l'età moderna e contemporanea 29-30 (1977-78), 219-76; and Silvana Seidel Menchi, 'Inquisizione come repressione o Inquisizione come mediazione? Una proposta di periodizzazione', Annuario dell'Istituto storico italiano per l'età moderna e contemporanea 35-36 (1983-84), 53-77. The enduring interest of Italian historiography in the ecclesiastical justice emerges also by Elena Brambilla's book Alle origini del Sant'Uffizio. Penitenza, confessione e giustizia spirituale dal medioevo al XVI secolo (Bologna: Il Mulino, 2000). Although it is not directly referred to the Inquisition, it is useful also the monograph by Wietse de Boer, The Conquest of the Soul. Confession, discipline and public order in Counter Reformation Milan (Leiden-Boston : Brill, 2001).

81. François Soyer, 'Was there an Inquisition in Portugal before 1536 ?', Iacobus 19-20 (2005), 177-205.

82. I refer to Joaquim Ramos de Carvalho, As visitas pastorais e a sociedade de Antigo Regime. Notas para o estudo de um mecanismo de normalização social (Coimbra, 1985) ; Id., 'A jurisdição episcopal sobre leigos em matéria de pecados públicos : as visitas pastorais e o comportamento moral das populações portuguesas do Antigo Regime', Revista Portuguesa de História 24 (1988), 12-163 ; José Pedro Paiva, 'A admininistração diocesana e a presença da Igreja. O caso da diocese de Coimbra nos séculos XVII-XVIII', Lusitania Sacra s. 2, 3 (1991), 71-110; Id., 'La Réforme catholique au Portugal. Les visites pastorales des évêques', Arquivos do Centro Cultural Calouste Gulbenkian 43 (2002), 159-75.

83. José Pedro Paiva, 'Inquisição e visitas pastorais. Dois mecanismo complementares de controle social ?', Revista de História das Ideias 10 (1989), 85-102.

84. Elvira Cunha de Azevedo Mea, 'O procedimento inquisitorial garante da deputação das visitas pastorais de Braga (Século XVI)', in IX Centenário da Dedicação da Sé de Braga. Actas do congresso internacional, 4 vols. (Braga : Universidade Católica Portuguesa, 1990), 2/2:67-95.

85. Sentenças da Inquisição de Coimbra em metropolitanos de D. Frei Bartolomeu dos Mártires, 1567-1582, introd. e leit. Elvira Cunha de Azevedo Mea (Porto: Arquivo Histórico Dominicano PortuguêsMovimento Bartolomeano, 1982). 
86. Giuseppe Marcocci 'Il governo dell'arcidiocesi di Braga al tempo di Bartolomeu dos Mártires (1559-1582)', Archivio italiano per la storia della pietà 15 (2002), 81-150; Id., 'Catequização pelo medo ?. I refer to Stefania Pastore, Il Vangelo e la spada. L'Inquisizione di Castiglia e i suoi critici, 1460-1598 (Roma : Edizioni di Storia e Letteratura, 2003) ; and to Vincenzo Lavenia, 'Assolvere o infamare. Eresia occulta, correzione fraterna e segreto sacramentale', Storica 20-21 (2001), 89-154.

87. Marcocci, I custodi dell'ortodossia. See Federico Palomo, Fazer dos campos escolas excelentes. Os jesuítas de Évora e as missões do interior em Portugal, 1551-1630 (Lisboa: Fundação Calouste Gulbenkian-FCT, 2003).

88. What I wrote on confession in ch. 5 of the book I custodi dell'ortodossia was completed by my essay 'La salvezza dei condannati a morte. Giustizia, conversioni e sacramenti in Portogallo e nel suo impero, 1450-1700 ca.', in Misericordie. Conversioni sotto il patibolo tra Medioevo ed età moderna, a cura di Adriano Prosperi (Pisa : Edizioni della Normale, 2007), 189-255.

89. José Pedro Paiva, 'Les évêques et l'Inquisition portugaise (1536-1613)', in Inquisition et pouvoir, sous la dir. de Gabriel Audisio (Aix-en-Provence : Publications de l'Université de Provence, 2004), 147-69.

90. Id., Os bispos de Portugal e do Império, 1495-1777 (Coimbra: Imprensa da Universidade de Coimbra, 2006), a book that I reviewed in Studi Storici 48 (2007), 551-5.

91. Giuseppe Marcocci, '« ... per capillos adductos ad pillam». Il dibattito cinquecentesco sulla validità del battesimo forzato degli ebrei in Portogallo (1496-1497)', in Salvezza delle anime, disciplina dei corpi. Un seminario sulla storia del battesimo, a cura di Adriano Prosperi (Pisa : Edizioni della Normale, 2006), 341-423; Bruno Feitler, 'O catolicismo como ideal. Produção literária antijudaica no mundo português da Idade Moderna', Novos Estudos 72 (2005), 137-58.

92. José Pedro Paiva, 'Bispos, imprensa, livro e censura no Portugal de Quinhentos', Revista de História das Ideias 28 (2007), 687-737 ; Id., 'Una Chiesa forte e compatta : Sant'Uffizio e vescovi nel Portogallo moderno, secoli XVI-XVIII', in A dieci anni dall'apertura dell'archivio [in press] ; Giuseppe Marcocci, 'O arcebispo de Braga, D. Frei Bartolomeu dos Mártires (1559-1582). Um caso de inquisição pastoral ?', Revista de História da Sociedade e da Cultura 9 (2009), 119-46.

93. Id., 'Inquisição, jesuítas e cristãos-novos em Portugal no século XVI', Revista de História das Ideias 25 (2004), 247-326; José Pedro Paiva, 'Os Dominicanos e a Inquisição em Portugal (1536-1614)', in La orden dominicana y la Inquisición en el mundo ibérico e hispanoamericano, ed. Arturo Bernal Palacios (Roma : Istituto Storico Domenicano, 2006), 505-73.

94. Evergton Sales Souza, Jansénisme et Réforme de l'Église dans l'Empire Portugais, 1640 à 1790 (Paris : Fundação Calouste Gulbenkian, 2004).

95. António Pereira da Silva, A questão do sigilismo em Portugal no século XVIII. História, religião e política nos reinados de D. João V e D. José (Braga, 1964); Adriano Prosperi, 'Il sigillo infranto: confessione e Inquisizione in Portogallo nel '700', in Id., L'Inquisizione romana, 413-33.

96. Bruno Feitler, 'L'Inquisizione universale e le Inquisizioni nazionali : tracce per uno studio sui rapporti tra il Sant'Uffizio romano e i tribunali iberici', in Le inquisizioni cristiane, 115-21. There are more works on the relationship between the Inquisitions of Portugal and Spain. See François Soyer, 'An example of collaboration between the Spanish and Portuguese Inquisitions. The Trials of the 'Converso' Diogo Ramos and his Family', Cadernos de Estudos Sefarditas 6 (2006), 317-40 ; and Id., 'The Extradition Treaties of the Spanish and Portuguese Inquisitions (1500-1700)', Estudios de Historia de España 10 (2008), 201-38, in which are recovered episodes and figures that were also studied by Rafael Carrasco, 'Preludio al "siglo de los portugueses”. La Inquisición de Cuenca y los judaizantes en el siglo XVI', Hispania 47 (1987), 503-59; Pilar Huerga Criado, En la raya de Portugal. Solidaridad y tensiones en la comunidad judeoconversa (Salamanca: Ediciones de la Universidad de Salamanca, 1993), 222-30 ; Isabel M.R.M. Drumond Braga, Um Espaço, Duas Monarquias (Interrelações na Península Ibérica no Tempo de Carlos V) (Lisboa: Universidade Nova de Lisboa-Hugin, 2001), 553-83. For the Roman Inquisition see Pier Cesare Ioly Zorattini, 'Un profilo del marranesimo alla 
fine del '500: la denuncia al Sant'Uffizio di Fra' Zaccaria da Lisbona', in Mémorial I.-S. Révah, 529-43.

97. Significantly, in the same year India regained the sovereignty over Goa by force, was published the well-documented, but controversial book by Anant Kakba Priolkar, The Goa Inquisition. Being a Quatercentenary Commemoration Study of the Inquisition in India (Bombay : Bombay University Press, 1961).

98. Laura de Mello e Souza, o Diabo e a Terra de Santa Cruz. Feitiçaria e religiosidade popular no Brasil Colonial (São Paulo : Companhia das Letras, 1987) ; English trans. The Devil and the Land of the Holy Cross. Witchcraft, Slavery and Popular Religion in Colonial Brazil (Austin : University of Texas Press, 2003). This line of research was shared by Helen Ulhôa Pimentel in her Ph.D. dissertation, Universo mágico colonial. Feiticeiros e Inquisidores nos dois primeiros séculos da colonização do Brasil (Brasília : Universidade de Brasília, 2005). The progress of the historiography pertaining to Brazil can be compared with that made for Mexico thanks to Fernando Cervantes, The Devil in the New World. The impact of diabolism in New Spain (New Haven : Yale University Press, 1994).

99. Bruno Feitler, 'Usos políticos del Santo Oficio portugués en el Atlántico (Brasil y África Occidental). El período filipino', Hispania Sacra 59 (2005), 137-58.

100. Nathan Wachtel, La foi du souvenir. Labyrinthes marranes (Paris : Seuil, 2001). An example of continuity of the historiographic tradition inaugurated by Novinsky is to be found in Ensaios sobre a intolerância.

101. Bruno Feitler, Inquisition, juifs et nouveaux-chrétiens au Brésil. Le Nordeste, XVII ${ }^{e}$-XVIII ${ }^{e}$ (Louvain : Presses Universitaires de Louvain, 2003) ; Ricardo Escobar Quevedo, Inquisición y judaizantes en América española, siglos XVI-XVII (Bogotá : Universidad del Rosario, 2008).

102. Ronaldo Vainfas, Trópico dos pecados : moral, sexualidade e Inquisição no Brasil (Rio de Janeiro : Campus, 1989).

103. Ronaldo Vainfas, A heresia dos índios. Catolicismo e rebeldia no Brasil colonial (São Paulo: Companhia das Letras, 1995). Moves away from him Alida C. Metcalf, 'Millenarian Slaves? The 'Santidade de Jaguaripe' and Slave Resistance', American Historical Review 104 (1999), 1531-59. On the inquisitorial control of the religious life of local population and slaves see also James E. Wadsworth, 'Jurema and Batuque: Indians, Africans and the Inquisition in Colonial Northeastern Brazil', History of Religions 46:2 (2006), 140-62.

104. From the point of view of the institutional history of Spanish Inquisition stand out the recent studies about the tribunal of Lima : Paulino Castañeda Delgado-Pilar Hernández AparicioRené Millar Carvacho, La Inquisición de Lima, 3 vols. (Madrid : Deimos, 1989-1998) ; Teodoro Hampe Martínez, Santo Oficio e historia colonial. Aproximaciones al tribunal de la Inquisición de Lima, 1570-1820 (Lima : Congreso de la República del Perú, 1998); René Millar Carvacho, Inquisición y sociedad en el Virreinato Peruano. Estudios sobre el tribunal de la Inquisición de Lima (Lima : Pontificia Universidad Católica de Perú ; Santiago : Universidad Católica de Chile, 1998).

105. Laura de Mello e Souza, Inferno atlântico. Demonologia e colonização, séculos XVI-XVII (São Paulo: Companhia das Letras, 1993); Stuart B. Schwartz, All Can Be Saved. Religious Tolerance and Salvation in the Iberian Atlantic World (New Haven : Yale University Press, 2008).

106. Geraldo Pieroni, Os excluídos do reino. A Inquisição portuguesa e o degredo para o Brasil colônia (Brasília : Universidade de Brasília ; São Paulo : Imprensa Oficial do Estado, 2000). For an example of the current trends see A Inquisição em xeque. Temas, controvérsias, estudos de caso, orgs. Ronaldo Vainfas, Bruno Feitler e Lana Lage da Gama Lima (Rio de Janeiro : Eduerj, 2005).

107. James E. Wadsworth, 'In the Name of the Inquisition. The Portuguese Inquisition and Delegated Authority in Colonial Pernambuco, Brazil', The Americas 61 (2004), 19-54. The topic is discussed more clearly in the translation of Feitler's book mentioned in footnote 101 : Nas malhas da consciência. Igreja e Inquisição no Brasil (São Paulo : Alameda-Phoebus, 2007).

108. Ronaldo Vainfas, Traição. Um jesuíta a serviço do Brasil holandês processado pela Inquisição (São Paulo : Companhia das Letras, 2008). 
109. Ana Margarida Santos Pereira, A Inquisição no Brasil. Aspectos da sua actuação nas capitanias do Sul de meados do séc. XVI ao início do séc. XVIII (Coimbra : FLUC, 2006).

110. José Alberto R. S. Tavim, Os judeus na Expansão portuguesa em Marrocos durante o século XVI. Origens e actividades duma comunidade (Braga : APPACDM, 1997); see also Id., 'Uma 'estranha tolerância' da Inquisição portuguesa. Belchior Vaz de Azevedo e o interesse das potências europeias por Marrocos (segunda metade do século XVI)', in Entre el Islam y Occidente. Los judíos magrebies en la Edad Moderna, ed. Mercedes García-Arenal (Madrid: Casa de Velázquez, 2003), 101-23 ; A Inquisição em África, orgs. Francisco Bethencourt-Philippe Havik, in Revista Lusófona de Ciência das Religiões 3 (2004), 19-173.

111. On sources for the history of Goa Inquisition see José Alberto R. S. Tavim, 'Um inquisidor inquirido : João Delgado Figueira, no contexto da "documentação sobre a Inquisição de Goa" ', Leituras. Revista da Biblioteca Nacional s. 3, 1 (1997), 183-93.

112. James C. Boyajian, 'Goa Inquisition. A New Light on the First 100 Years, 1561-1660', Purabhilekh-Puratatva 4 (1986), 1-40, recovered in Id., Portuguese Trade in Asia under the Habsburgs, 1580-1640 (Baltimore: The Johns Hopkins University Press, 1993). See also Ana Isabel Cannas da Cunha, A Inquisição e o Estado da Índia. Origens, 1539-1560 (Lisboa : ANTT, 1995).

113. Jose Alberto R. S. Tavim, Judeus e Cristãos-Novos de Cochim. História e Memória, 1500-1662 (Braga : APPACDM, 2003) ; Charles Amiel, 'L'Inquisition de Goa', in L'Inquisizione. Atti, 229-50. Preliminary studies about the activity of Goa Inquisition are : Maria de Jesus dos Mártires Lopes, 'A Inquisição de Goa na segunda metade do século XVIII. Contributo para a sua história', Studia 48 (1989), 237-62 ; Ead., 'A Inquisição de Goa na primeira metade de Setecentos: uma visita pelo seu interior', Mare Liberum 15 (1998), 107-36 ; José Alberto R. S. Tavim, 'A Inquisição no Oriente (século XVI e primeira metade do século XVII)', Mare Liberum 15 (1998), 17-31.

114. L'Inquisition de Goa. La relation de Charles Dellon (1687), étude, édition et notes de Charles Amiel et Anne Lima (Paris : Chandeigne, 1997).

115. Bruno Feitler, 'A delegação de poderes inquisitoriais: o exemplo de Goa através da documentação da Biblioteca Nacional do Rio de Janeiro', Tempo 24 (2008), 127-48. About the documentation on Goa existing in Brazil see 'Inquisição de Goa : inventário analítico', ed. Carmen Tereza Coelho Moreno, Anais da Biblioteca Nacional 120 (2000) [2006], 7-272.

116. Sanjay Subrahmanyam, 'Dom Frei Aleixo de Meneses (1559-1617) et l'échec des tentatives du christianisme en Inde. L'indigénisation du christianisme en Inde pendant la période coloniale (1498-1947)', Archives des sciences sociales des religions 103 (1998), 21-42 ; Inês G. Županov, “'One Civility, But Multiple Religion". Jesuit Mission among St. Christians in India (16th-17th Centuries)', Journal of Early Modern History 9 (2005), 284-325 ; Ead., 'Conversion Historiography in South Asia : Alternative Indian Christian Counter-histories in Eighteenth Century Goa', Medieval History Journal 12 (2009), 303-25. See also the recent book by Ângela Barreto Xavier, A Invenção de Goa. Poder imperial e conversões culturais nos séculos XVI e XVII (Lisboa : ICS, 2008).

117. Caio Boschi, 'Estruturas eclesiásticas e Inquisição', in História da Expansão Portuguesa, dir. Francisco Bethencourt e Kirti Chauduri, 5 vols. (Lisboa : Círculo de Leitores, 1998), 2:429-52. My essay is entitled 'La fede di un impero : l'Inquisizione nel mondo portoghese del ' 500 ', in A dieci anni dall'apertura [in press].

118. I have dedicated my recent article 'A fundação da Inquisição em Portugal : um novo olhar', Lusitania Sacra s. 2, 22 (2010) [in press] to the question of the foundation of the Holy Office. After the brief essay on the abolition of the tribunal by Francisco Bethencourt, 'Declínio e extinção do Santo Ofício', Revista de História Económica e Social 20 (1987), 77-85, Pedro Vilas Boas Tavares once again returned to this subject in his article 'Da reforma à extinção : a Inquisição perante as Luzes', Revista da Faculdade de Letras. Línguas e Literaturas 19 (2002), 171-208. 


\section{ABSTRACTS}

The Portuguese Inquisition's general history has yet to be written. This article explores the reason of such a surprising dearth, in a close comparison with the Italian and Spanish cases. A wide range of works is here discussed in order to promote a perspective from which the first critical synthesis on the Portuguese Inquisition could come to light. Firstly, classic historiography will be analyzed up to the 'Carnation Revolution' (1974). Since then, modern historiography has remarkably developed. So, the focus will be on the three main lines of research on a court that marked the religious life of early modern Portugal : the relationship of the Inquisition with State and society; the collaboration between the inquisitors and other ecclesiastical agents, as well as the forms of resistance from inside the Church ; the multifaceted action of the Inquisition in the colonial empire.

L'histoire générale de l'Inquisition portugaise attend encore d'être écrite. Le présent article sonde les raisons de cette étonnante absence, par comparaison avec les cas italien et espagnol. Une vaste sélection de travaux est discutée ici dans le but de dégager une perspective et de permettre une première synthèse critique sur l'Inquisition portugaise. Après un bref examen de l'historiographie classique jusqu'à la Révolution des CFillets (1974), on soulignera les remarquables progrès réalisés par l'historiographie moderne dans trois directions de recherche sur un tribunal qui a marqué profondément la vie religieuse portugaise à l'époque moderne : les relations de l'Inquisition avec l'État et la société; la collaboration entre les inquisiteurs et d'autres membres du clergé, ainsi que les formes de résistance à l'intérieur de l'Église ; l'action aux multiples facettes de l'Inquisition dans l'empire colonial.

\section{AUTHOR}

\section{GIUSEPPE MARCOCCI}

Scuola Normale Superiore, Pisa (Italy)

Piazza dei Cavalieri, 756126 Pisa, ITALY

g.marcocci@sns.it 